\title{
Article
}

\section{Research on Operation Safety of Offshore Wind Farms}

\author{
Junmin Mou ${ }^{1,2}$, Xuefei Jia ${ }^{1}$, Pengfei Chen ${ }^{1,2}$ and Linying Chen ${ }^{1,2, *}$ \\ 1 School of Navigation, Wuhan University of Technology, Wuhan 430063, China; moujm@whut.edu.cn (J.M.); \\ Jiaxuefei215@whut.edu.cn (X.J.); Chenp£@whut.edu.cn (P.C.) \\ 2 Hubei Key Laboratory of Inland Shipping Technology, Wuhan University of Technology, \\ Wuhan 430063, China \\ * Correspondence: linyingchen@whut.edu.cn
}

Citation: Mou, J.; Jia, X.; Chen, P.; Chen, L. Research on Operation Safety of Offshore Wind Farms. J. Mar. Sci. Eng. 2021, 9, 881. https:// doi.org/10.3390/jmse9080881

Academic Editor: María Dolores Esteban Pérez

Received: 10 July 2021

Accepted: 14 August 2021

Published: 15 August 2021

Publisher's Note: MDPI stays neutral with regard to jurisdictional claims in published maps and institutional affiliations.

Copyright: (c) 2021 by the authors. Licensee MDPI, Basel, Switzerland. This article is an open access article distributed under the terms and conditions of the Creative Commons Attribution (CC BY) license (https:/ / creativecommons.org/licenses/by/ $4.0 /)$.

\begin{abstract}
The operation of offshore wind farms is characterized by a complicated operational environment, long project cycle, and complex vessel traffic, which lead to safety hazards. To identify the key factors affecting the operational safety of offshore wind farms, the risk characteristics of offshore wind farm operations are analyzed based on comprehensive identification of hazards and risk assessment theory. A systematic fault tree analysis of the offshore wind farm operation is established. The assessment shows that the key risk factors that induce offshore wind power collapse, corrosion, fire, lightning strikes, blade failure, personal injury, ship collision, and submarine cable damage accidents are gale, untimely overhauling, improper fire stopping methods, high average number of thunderstorm days, the loose internal structure of fan, working at height, collision avoidance failure, and insufficient buried depth of cables.
\end{abstract}

Keywords: offshore wind farm; fault tree analysis; operational safety; hazard identification

\section{Introduction}

Globally, the use of wind energy for power generation gains importance due to environmental benefits and the possible contribution to a safe energy provision [1]. The operation of offshore wind farms is characterized by a complicated operational environment, long project cycle, and complex vessel traffic, which lead to safety hazards. In 2019, 865 accidents occurred in offshore wind farms, which increased by $22.3 \%$ compared with 707 accidents in 2018 [2]. Therefore, it is essential to identify the risks and hidden dangers of offshore wind power to water traffic and personnel safety.

At present, most studies on risk assessment for offshore wind farms start from a single object, such as infrastructure [3-6], offshore wind power equipment and personnel safety [7-10], and navigation waters of offshore wind farms [11-13]. For infrastructure risks, the majority of coating damages on offshore wind power platforms can be attributed to unsuitable constructive design and mechanical loading [3]. Seawater is corrosive compared to drinking water and temperature affects corrosion processes [4]. Price and Figueira [5] found that corrosion has different types. In addition, waves and wind can initiate stress corrosion cracking and corrosion fatigue. For offshore wind power equipment and personnel risks, literature [6] pointed out that strong wind and fractured bolts during construction may affect the offshore wind turbine's life. Fire is also the main accident of focus. An electrical fire prevention system for an offshore wind turbine in [7] was implemented according to the risk characteristics of the fire accident. A method to evaluate the lightning strike rate of the entire offshore wind farms was proposed in [8]. Literature [9] pointed out that people working in offshore wind farms encountered sleep quality problems. Chao et al. [10] established a time-varying analytical model for the WT failure rate affected by wind speed and lightning. For navigation waters of offshore wind farms' risks, collision is a common event in the navigation risks of offshore wind farms. The Automatic Identification System is used to analyze the risk of ship collision with offshore platforms in [11]. 
Literature [12] described the impact of the operation and maintenance ship on the fan at different speeds in detail. The submarine power cable of the offshore wind farm, used for connecting power generation devices to onshore equipment, may have a significant impact on navigation safety [13]. Both qualitative and quantitative technologies have been used to measure the risk of wind farm operations. Representative qualitative analysis methods are Fault Mode Analysis Method [14], Tree Chart Analysis [15], SWOT (Strengths Weaknesses Opportunities Threats) [16]. Representative quantitative methods are Bayesian method [17-19], Monte Carlo Analysis [20], and reliability-based design optimization tools $[21,22]$. However, the operation of the offshore wind farm is systematic. All the components and factors are closely connected. Focusing on a certain object may lead to underestimation of the risk of the whole system.

Therefore, in this paper, we carry out a systematic analysis on the operation safety of offshore wind farms from the perspectives of infrastructure, offshore wind power equipment and personnel safety, and navigation waters. To identify the key factors affecting operational safety, the risk characteristics of offshore wind farm operations are analyzed based on comprehensive identification of hazards and risk assessment theory. The fault tree analysis of the offshore wind farm operation is established. Qualitative and quantitative analyses on the operation risk are carried out according to questionnaires and expert judgment. Instead of the probability of occurrence of the basic event, a risk index is proposed to illustrate the contribution of each basic event to the top event. The risk index is a quantitative assessment of the opinions of the experts according to the questionnaires responded by 50 experts who have worked in offshore wind farms for more than 2 years. Finally, the risk of infrastructure, offshore wind power equipment, and personnel safety, as well as navigation waters to the operation of offshore wind farms are obtained.

The remainder of this paper is arranged as follows: Section 2 provides the mythology of this article. Sections 3-5 provides the risk analysis for offshore wind farm infrastructure risks, equipment and personnel risks, and navigation risks, respectively. In Section 6, we discuss the main findings and measures to improve the safety of the operation of offshore wind farms. Section 7 concludes the article and provides future research directions.

\section{Methodology}

Fault tree analysis (FTA) is applied to carry out a top-down, deductive failure analysis for the offshore wind farm operation. The undesired state of the wind farm and related events are identified and connected using Boolean logic to understand how systems can fail, and how to reduce the risk. The methodology of this paper is shown in Figure 1.

First, the operation data of offshore wind farms are collected by literature reading and field research. The data are analyzed to find out the characteristics of wind farm accidents and the causes of risks. An overview of accidents and risk factors in related research is provided in Appendix A. According to the natural environment and navigation environment, the risks are divided into three categories: offshore wind power infrastructure risks, including collapse, corrosion, and other risks; wind power and electrical equipment risks, including fire, lightning, blade failure, personnel injury, and other accidents, and navigable waters risks, including collision, and cable accidents.

Secondly, based on the Fault Tree Analysis, the logical analysis of the risk causes is carried out to determine the top events, intermediate events, and basic events based on the collected data. After the basic events are identified, the risk source questionnaire of the offshore wind farm is carried out, and the questionnaire is distributed to the people who have worked in offshore wind farms for more than 2 years. The questionnaire is provided in the Appendix B; 60 questionnaires are collected and 50 are valid. The respondents are the staff of the offshore wind farms located in Hangzhou Bay. The wind farms are about $20 \mathrm{~km}$ from shore, and the water depth is $8-12 \mathrm{~m}$. A risk index which is the mean value of the answers is used to represent the contribution of each basic event to the top event. The risk of the top events, i.e., infrastructure, offshore wind power equipment, and personnel safety, and navigation waters during the operation of offshore wind farms are then obtained. 


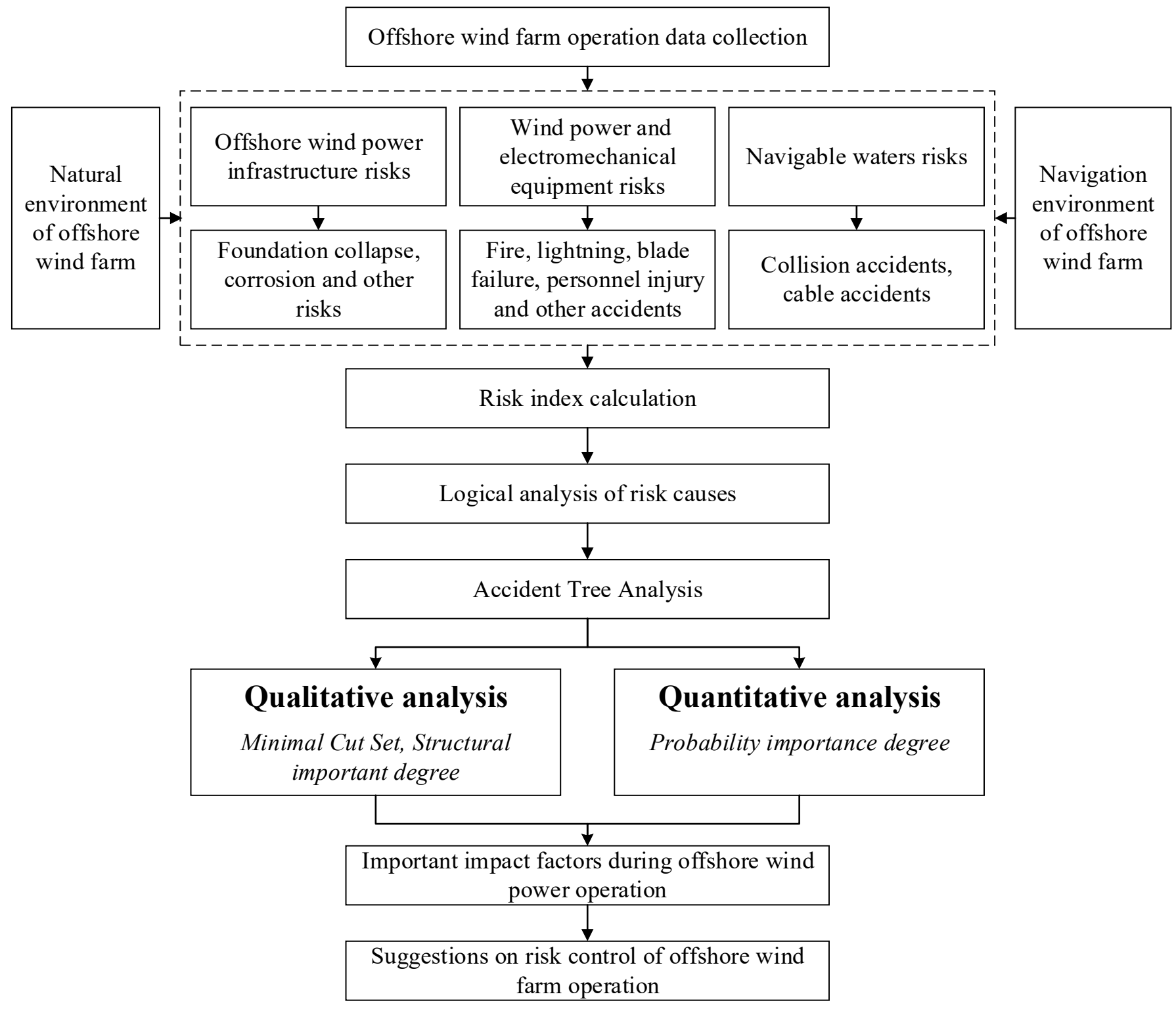

Figure 1. Methodology.

Thirdly, the risk of the wind farm operation is assessed using the Isograph Reliability Workbench (x64, 13.013.0). The minimum cut set, structural important degree, and probability importance degree are provided. Identification of minimal cut sets is one of the most important qualitative analyses of a fault tree. The top event occurs if one or more of the minimal cut sets occur. The structural importance degree analyzes the importance of each basic event from the structure of the fault tree. Quantitative analysis of the probability importance degree of the basic events, which analyzes the impact of changes in the probability of basic events on top events. The Fussell-Vesely importance degree [23] is applied in this manuscript. The Fussell-Vesely importance is the probability, given that a critical failure has occurred, that at least one minimal cut set containing a particular element contributed to that failure, which can be approximated by

$$
I^{F V}(i \mid t) \approx \frac{1-\prod_{j=1}^{m_{i}}\left(1-\left(\check{Q}_{j}^{i}(t)\right)\right.}{Q_{0}(t)} \approx \frac{\sum_{j=1}^{m_{i}} \check{Q}_{j}^{i}(t)}{Q_{0}(t)}
$$

where $\check{Q}_{j}^{i}(t)$ denotes the probability that minimal cut set $j$ among those containing component $i$ is failed at time $t$. 
In the end, the important influencing factors that affect offshore wind power operation are identified. Accordingly, safety management measures for each typical event are formulated.

\section{Infrastructure Risks}

\subsection{Fault Tree for Infrastructure Risk}

This section describes the fault tree analysis of collapse (see Figure 2) and corrosion (see Figure 3). The use of the logic gate, i.e., AND gate and OR gate, is based on existing related research and expert judgment. For example, 'Poor foundation stability' and 'External force' are connected by an AND gate in Figure 2. Theoretically, a significant earthquake should be able to cause the collapse of a wind turbine no matter if the foundation stability is good or poor. However, on the one hand, in reality, the offshore wind turbine is usually established more than $20 \mathrm{~km}$ away from the shore and as well as avoiding choosing the water area with the most possible significant earthquakes. On the other hand, the influence of earthquakes cannot be underestimated. Accordingly, 'Poor foundation stability' and 'External force' are connected by an AND gate.

\subsection{Risk Index of the Basic Events}

According to the questionnaires, the risk index of the basic events in the fault tree for collapse and corrosion are provided in Tables 1 and 2.

Table 1. Collapse risk factors of offshore wind farms.

\begin{tabular}{lcc}
\hline Number & Risk Factor & Risk Index \\
\hline$c_{A} 1$ & Tight deadlines & 0.5104 \\
$c_{A} 2$ & Unsafe construction & 0.491 \\
$c_{A} 3$ & Imperfect maintenance & 0.5004 \\
$c_{A} 4$ & Ship that lose stability & 0.523 \\
$c_{A} 5$ & Ship that is anchored near the wind turbine & 0.423 \\
$c_{A} 6$ & Inappropriate parameter settings for anti-lift of pile foundation & 0.529 \\
$c_{A} 7$ & Inappropriate parameter settings for anti-overturning & 0.5278 \\
$c_{A} 8$ & Unreasonable structure design & 0.5416 \\
$c_{A} 9$ & Loose bolts & 0.5184 \\
$c_{A} 10$ & Insufficient bolt strength & 0.548 \\
$c_{A} 11$ & Insufficient load bearing capacity of the foundation & 0.5926 \\
$c_{A} 12$ & Inaccurate hydrographic survey & 0.4682 \\
$c_{A} 13$ & Inaccurate geological survey & 0.528 \\
$c_{A} 14$ & Inappropriate corrosion prevention methods & 0.4756 \\
$c_{A} 15$ & No corrosion prevention methods for the infrastructure & 0.5408 \\
$c_{A} 16$ & Tide & 0.3402 \\
$c_{A} 17$ & Gale & 0.5312 \\
$c_{A} 18$ & Earthquake & 0.4462 \\
\hline
\end{tabular}

Table 2. Corrosion risk factors of offshore wind farms.

\begin{tabular}{ccc}
\hline Number & Risk Factor & Risk Index \\
\hline$c_{B} 1$ & Untimely overhauling & 0.5146 \\
$c_{B} 2$ & Improper anti-corrosion measures & 0.539 \\
$c_{B} 3$ & Improper equipment selection & 0.423 \\
$c_{B} 4$ & Salt spray & 0.5384 \\
$c_{B} 5$ & Tide & 0.3702 \\
$c_{B} 6$ & Marine organisms attached to the equipment structure & 0.39 \\
$\mathrm{c}_{\mathrm{B}} 7$ & Scouring & 0.4012 \\
$\mathrm{c}_{\mathrm{B}} 8$ & Metal structure of steel & 0.4416 \\
\hline
\end{tabular}




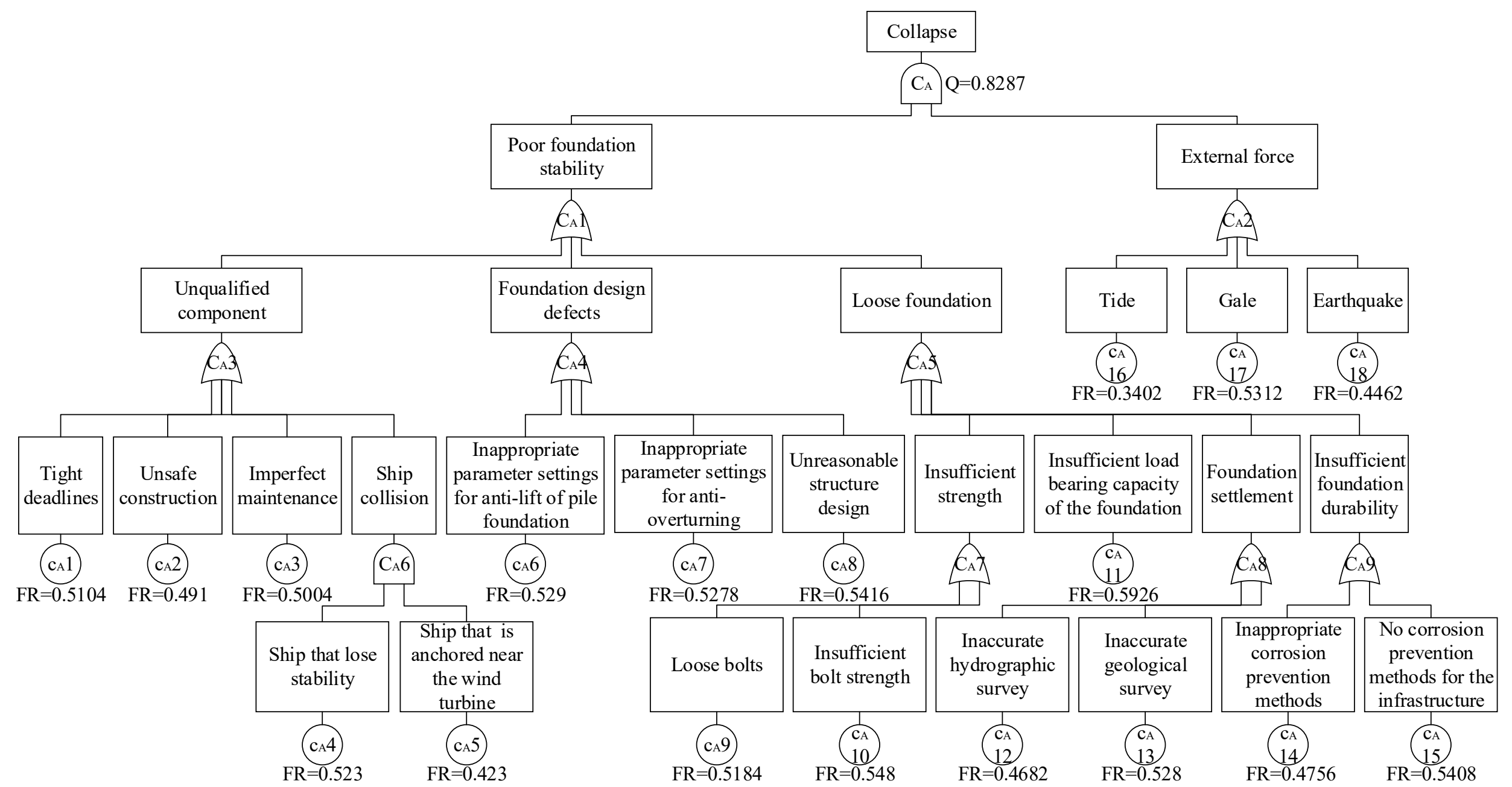

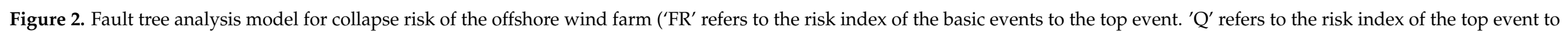
the offshore wind farm during operation). 


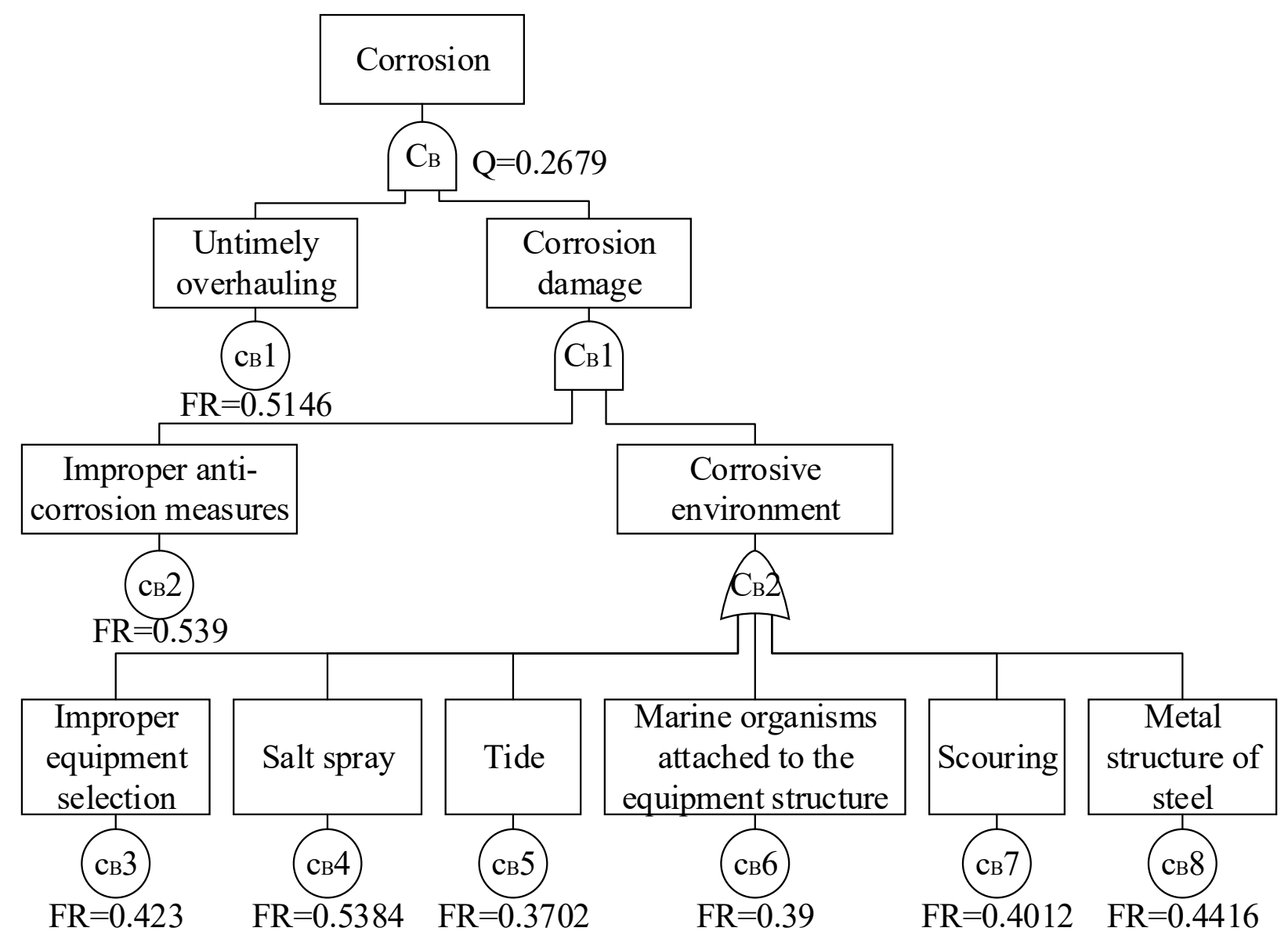

Figure 3. Fault tree analysis model for corrosion risk of the offshore wind farm.

\subsection{Risk Assessment}

(1) Risk assessment of collapse

With the help of Isograph Reliability Workbench, the minimum cut set, structural importance degree, and probability importance degree of the collapse accidents are analyzed as follows.

There are 42 minimum cut sets of collapse accidents:

- Second-order minimum cut sets: $\left\{c_{A} 11, c_{A} 17\right\},\left\{c_{A} 10, c_{A} 17\right\},\left\{c_{A} 8, c_{A} 17\right\},\left\{c_{A} 15, c_{A} 17\right\}$, $\left\{c_{A} 6, c_{A} 17\right\},\left\{c_{A} 13, c_{A} 17\right\},\left\{c_{A} 7, c_{A} 17\right\},\left\{c_{A} 9, c_{A} 17\right\},\left\{c_{A} 1, c_{A} 17\right\},\left\{c_{A} 3, c_{A} 17\right\},\left\{c_{A} 11, c_{A} 18\right\}$, $\left\{c_{A} 2, c_{A} 17\right\},\left\{c_{A} 14, c_{A} 17\right\},\left\{c_{A} 12, c_{A} 17\right\},\left\{c_{A} 10, c_{A} 18\right\},\left\{c_{A} 8, c_{A} 18\right\},\left\{c_{A} 15, c_{A} 18\right\},\left\{c_{A} 6\right.$, $\left.c_{\mathrm{A}} 18\right\},\left\{c_{\mathrm{A}} 13, \mathrm{c}_{\mathrm{A}} 18\right\},\left\{\mathrm{c}_{\mathrm{A}} 7, \mathrm{c}_{\mathrm{A}} 18\right\},\left\{\mathrm{c}_{\mathrm{A}} 9, \mathrm{c}_{\mathrm{A}} 18\right\},\left\{\mathrm{c}_{\mathrm{A}} 1, \mathrm{c}_{\mathrm{A}} 18\right\},\left\{\mathrm{c}_{\mathrm{A}} 3, \mathrm{c}_{\mathrm{A}} 18\right\},\left\{\mathrm{c}_{\mathrm{A}} 2, \mathrm{c}_{\mathrm{A}} 18\right\},\left\{\mathrm{c}_{\mathrm{A}} 14\right.$, $\left.c_{A} 18\right\},\left\{c_{A} 12, c_{A} 18\right\},\left\{c_{A} 11, c_{A} 16\right\},\left\{c_{A} 10, c_{A} 16\right\},\left\{c_{A} 8, c_{A} 16\right\},\left\{c_{A} 15, c_{A} 16\right\},\left\{c_{A} 6, c_{A} 16\right\}$, $\left\{c_{A} 13, c_{A} 16\right\},\left\{c_{A} 7, c_{A} 16\right\},\left\{c_{A} 9, c_{A} 16\right\},\left\{c_{A} 1, c_{A} 16\right\},\left\{c_{A} 3, c_{A} 16\right\},\left\{c_{A} 2, c_{A} 16\right\},\left\{c_{A} 14, c_{A} 16\right\}$, $\left\{\mathrm{c}_{\mathrm{A}} 12, \mathrm{c}_{\mathrm{A}} 16\right\} ;$

- Third-order minimum cut sets: $\left\{c_{A} 4, c_{A} 5, c_{A} 17\right\},\left\{c_{A} 4, c_{A} 5, c_{A} 18\right\},\left\{c_{A} 4, c_{A} 5, c_{A} 16\right\}$.

The structural importance degree of collapse accidents is as follows:

$\mathrm{I}\left(\mathrm{c}_{\mathrm{A}} 18\right)=\mathrm{I}\left(\mathrm{c}_{\mathrm{A}} 17\right)=\mathrm{I}\left(\mathrm{c}_{\mathrm{A}} 16\right)>\mathrm{I}\left(\mathrm{c}_{\mathrm{A}} 15\right)=\mathrm{I}\left(\mathrm{c}_{\mathrm{A}} 14\right)=\mathrm{I}\left(\mathrm{c}_{\mathrm{A}} 13\right)=\mathrm{I}\left(\mathrm{c}_{\mathrm{A}} 12\right)=\mathrm{I}\left(\mathrm{c}_{\mathrm{A}} 11\right)=\mathrm{I}\left(\mathrm{c}_{\mathrm{A}} 10\right)=$ $\mathrm{I}\left(\mathrm{c}_{\mathrm{A}} 9\right)=\mathrm{I}\left(\mathrm{c}_{\mathrm{A}} 8\right)=\mathrm{I}\left(\mathrm{c}_{\mathrm{A}} 7\right)=\mathrm{I}\left(\mathrm{c}_{\mathrm{A}} 6\right)=\mathrm{I}\left(\mathrm{c}_{\mathrm{A}} 3\right)=\mathrm{I}\left(\mathrm{c}_{\mathrm{A}} 2\right)=\mathrm{I}\left(\mathrm{c}_{\mathrm{A}} 1\right)>\mathrm{I}\left(\mathrm{c}_{\mathrm{A}} 5\right)=\mathrm{I}\left(\mathrm{c}_{\mathrm{A}} 4\right)$.

The Fussell-Vesely Importance of the basic events of wind turbine collapse in offshore wind farms is shown in Figure 4. The order of probability importance is listed as follows: 


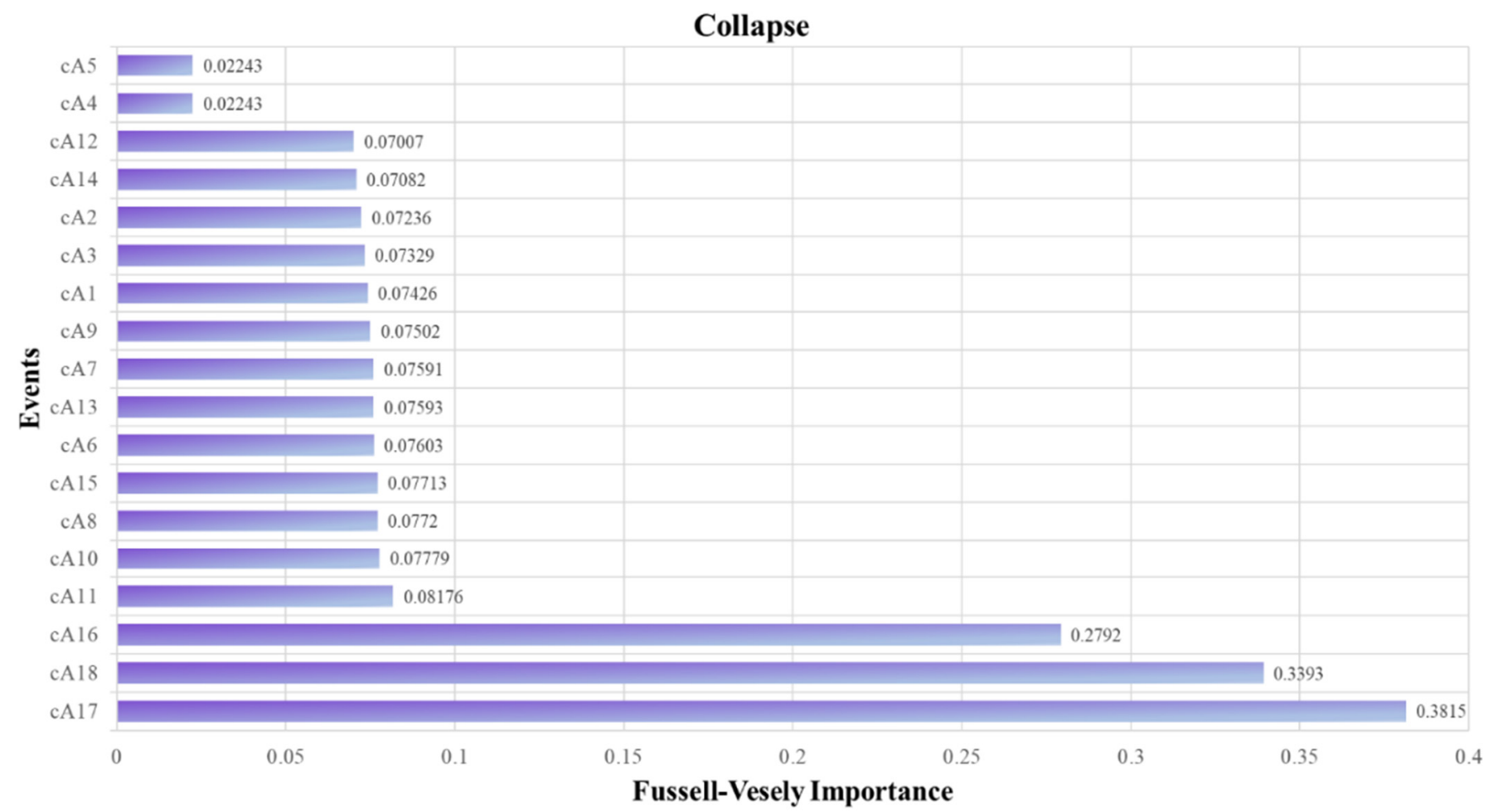

Figure 4. Fussell-Vesely Importance of each basic event of collapse accident.

Gale $\left(c_{A} 17\right)>$ Earthquake $\left(c_{A} 18\right)>\operatorname{Tide}\left(c_{A} 16\right)>$ Insufficient bearing capacity of the foundation $\left(c_{A} 11\right)>$ Insufficient bolt strength $\left(c_{A} 10\right)>$ Unreasonable structural design $\left(c_{A} 8\right)$ $>$ No corrosion prevention methods for the infrastructure $\left(\mathrm{c}_{A} 15\right)>$ Inappropriate parameter settings for anti-lift of pile foundation $\left(c_{A} 6\right)>$ Inaccurate geological survey $\left(c_{A} 13\right)>$ Inappropriate parameter settings for anti-overturning $\left(c_{A} 7\right)>$ Loose bolts $\left(c_{A} 9\right)>$ tight deadlines $\left(c_{A} 1\right)>$ Imperfect maintenance $\left(c_{A} 3\right)>$ Unsafe construction $\left(c_{A} 2\right)>$ Inappropriate corrosion prevention methods $\left(\mathrm{c}_{\mathrm{A}} 14\right)>$ Inaccurate hydrographic survey $\left(\mathrm{c}_{\mathrm{A}} 12\right)>$ Ships anchored near the wind turbine $\left(c_{A} 5\right)>$ Ships that lose stability $\left(c_{A} 4\right)$.

(2) Risk assessment of corrosion

With the help of Isograph Reliability Workbench, minimum cut set, structural importance degree, and probability importance degree of the corrosion accidents are as follows. There are 6 minimum cut sets of corrosion accidents:

- Third-order minimum cut sets: $\left\{c_{B} 1, c_{B} 2, c_{B} 4\right\},\left\{c_{B} 1, c_{B} 2, c_{B} 8\right\},\left\{c_{B} 1, c_{B} 2, c_{B} 3\right\},\left\{c_{B} 1, c_{B} 2\right.$, $\left.\mathrm{c}_{\mathrm{B}} 7\right\},\left\{\mathrm{c}_{\mathrm{B}} 1, \mathrm{c}_{\mathrm{B}} 2, \mathrm{c}_{\mathrm{B}} 6\right\},\left\{\mathrm{c}_{\mathrm{B}} 1, \mathrm{c}_{\mathrm{B}} 2, \mathrm{c}_{\mathrm{B}} 5\right\}$.

The structural importance degree of corrosion accidents is as follows:

$\mathrm{I}\left(\mathrm{c}_{\mathrm{B}} 2\right)=\mathrm{I}\left(\mathrm{c}_{\mathrm{B}} 1\right)>\mathrm{I}\left(\mathrm{c}_{\mathrm{B}} 8\right)=\mathrm{I}\left(\mathrm{c}_{\mathrm{B}} 7\right)=\mathrm{I}\left(\mathrm{c}_{\mathrm{B}} 6\right)=\mathrm{I}\left(\mathrm{c}_{\mathrm{B}} 5\right)=\mathrm{I}\left(\mathrm{c}_{\mathrm{B}} 4\right)=\mathrm{I}\left(\mathrm{c}_{\mathrm{B}} 3\right)$.

The Fussell-Vesely Importance of the basic events of wind turbine corrosion in offshore wind farms is shown in Figure 5. The order of probability importance is listed as follows: 


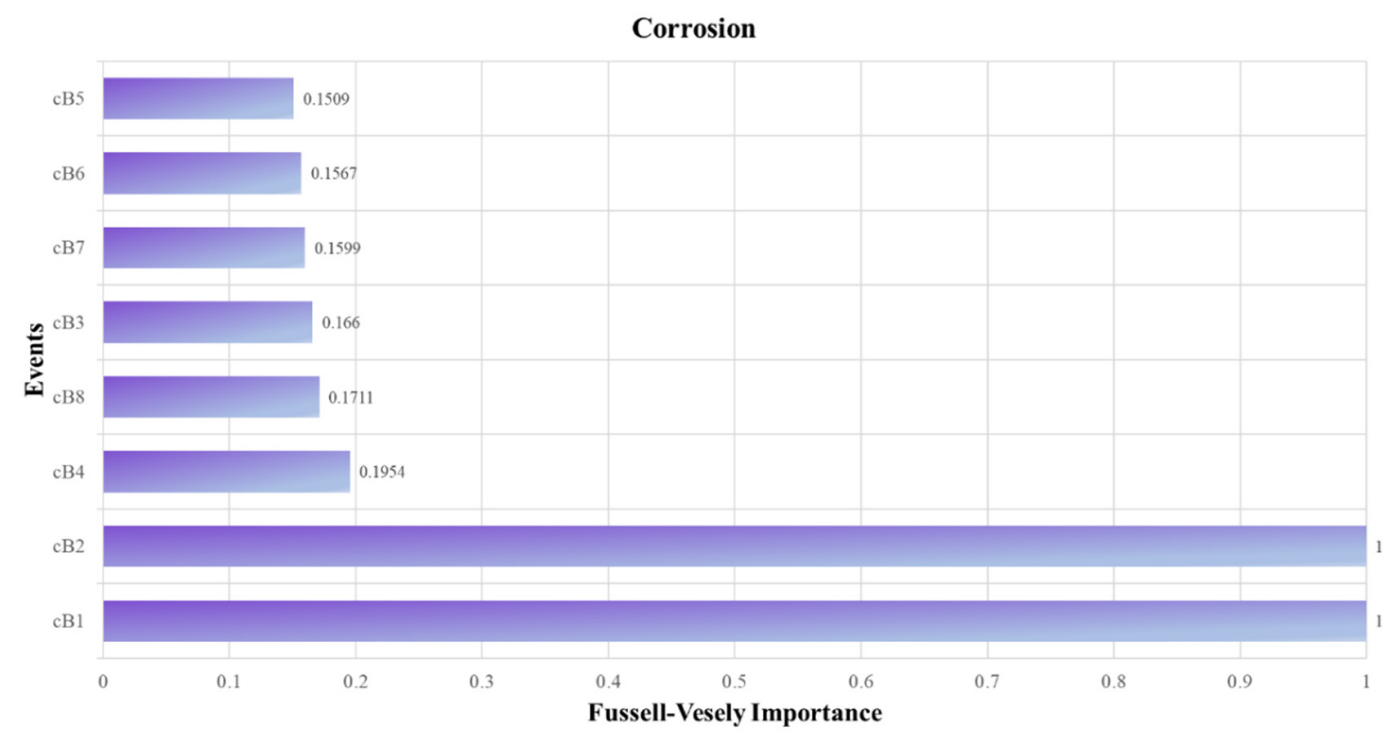

Figure 5. Fussell-Vesely Importance of each basic event of corrosion accident.

Untimely overhauling $\left(\mathrm{C}_{\mathrm{B}} 1\right)>\operatorname{Improper}$ anti-corrosion measures $\left(\mathrm{C}_{\mathrm{B}} 2\right)>$ Salt $\operatorname{spray}\left(\mathrm{C}_{\mathrm{B}} 4\right)$ $>$ Metal structure of steel $\left(\mathrm{c}_{\mathrm{B}} 8\right)>\operatorname{Improper}$ equipment selection $\left(\mathrm{c}_{\mathrm{B}} 3\right)>\operatorname{Scouring}\left(\mathrm{C}_{\mathrm{B}} 7\right)>$ Marine organisms attached to the equipment structure $\left(c_{B} 6\right)>\operatorname{Tide}\left(c_{B} 5\right)$.

\section{Equipment and Personnel Risk}

4.1. Fault Tree for the Equipment Failure and Personnel Injury

This section describes the fault tree analysis of fire (see Figure 6), a lightning strike (see Figure 7), blade failure (see Figure 8), and personnel injury (see Figure 9).

\subsection{Risk Index of the Basic Events}

According to the questionnaires, the risk index of the basic events in the fault tree for fire, lightning, blade failure, and personnel injury are provided in Tables 3-6.

Table 3. Fire risk factors of offshore wind farms.

\begin{tabular}{ccc}
\hline Number & Risk Factor & Risk Index \\
\hline f1 & Improper fire stopping methods & 0.4756 \\
f2 & Lightning strike & 0.5272 \\
f3 & Improper electrical operation & 0.4698 \\
f4 & Mechanical damage to electrical devices & 0.457 \\
f5 & Salt spray corrosion & 0.484 \\
f6 & Overload & 0.5292 \\
f7 & Vulnerabilities in device's manufacturing & 0.4728 \\
f8 & Violation of safety regulations & 0.5586 \\
f9 & Improper selection and installation of electrical devices & 0.5166 \\
f10 & Irrational design of electrical circuit & 0.5066 \\
f11 & Welding & 0.475 \\
f12 & Small space & 0.5052 \\
f13 & Overspeed & 0.5052 \\
f14 & Mechanical friction & 0.4904 \\
f15 & Poor ventilation & 0.4572 \\
f16 & Oil leakage & 0.4074 \\
f17 & Increases in Electrical Contact Resistance & 0.483 \\
\end{tabular}




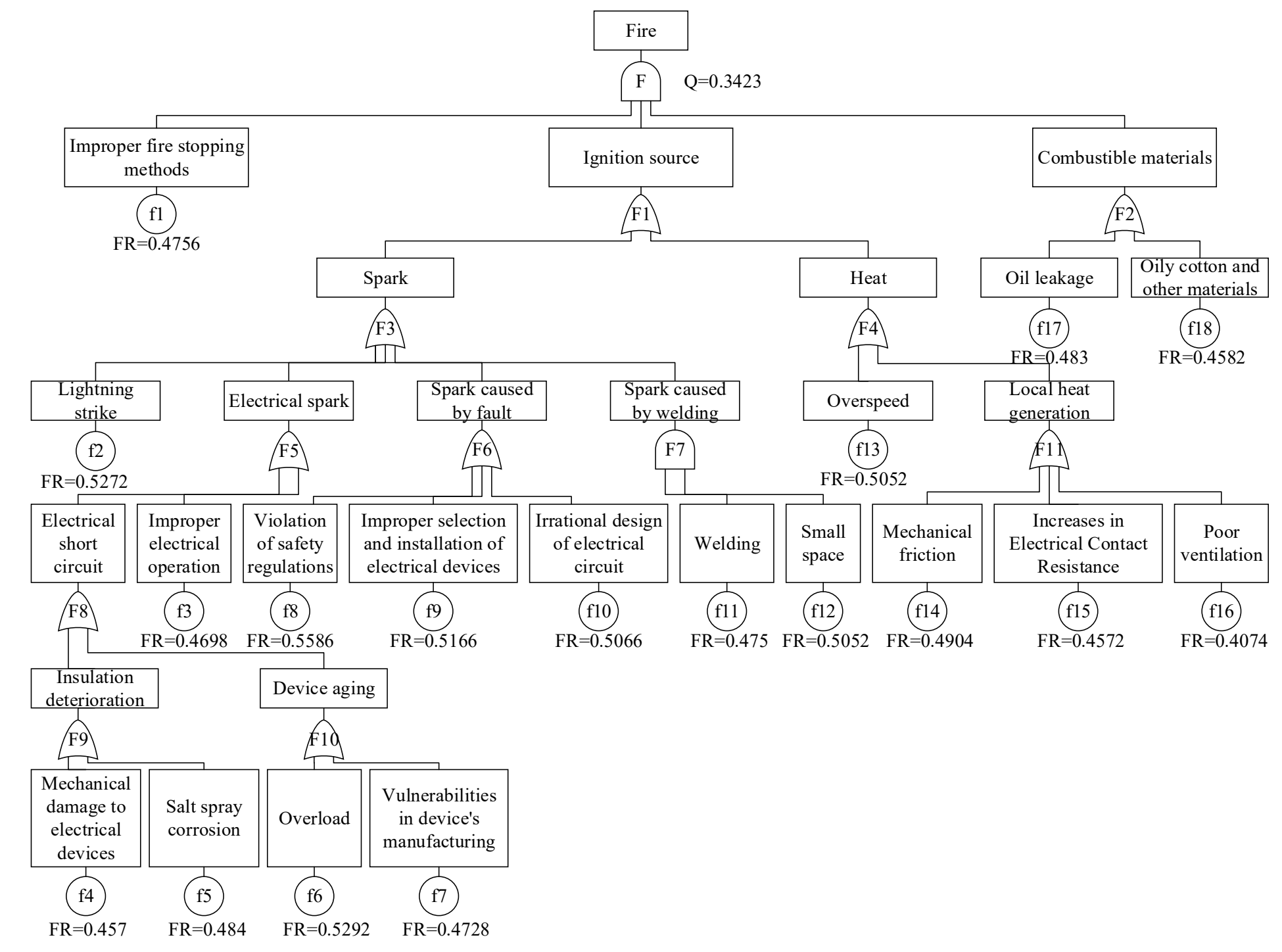

Figure 6. Fault tree analysis model for fire risk of the offshore wind farm. 


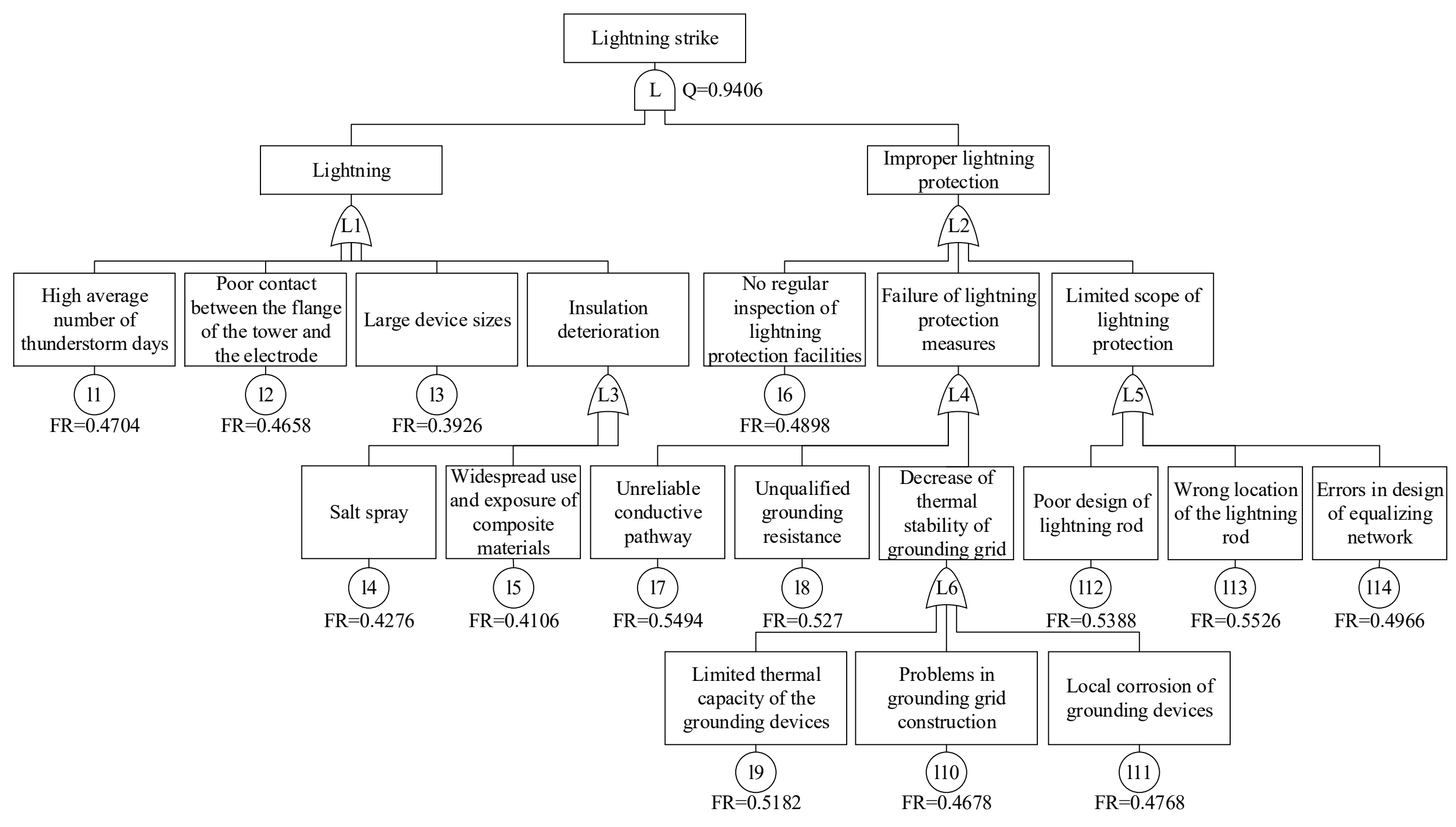

Figure 7. Fault tree analysis model for lightning strike risk of the offshore wind farm. 


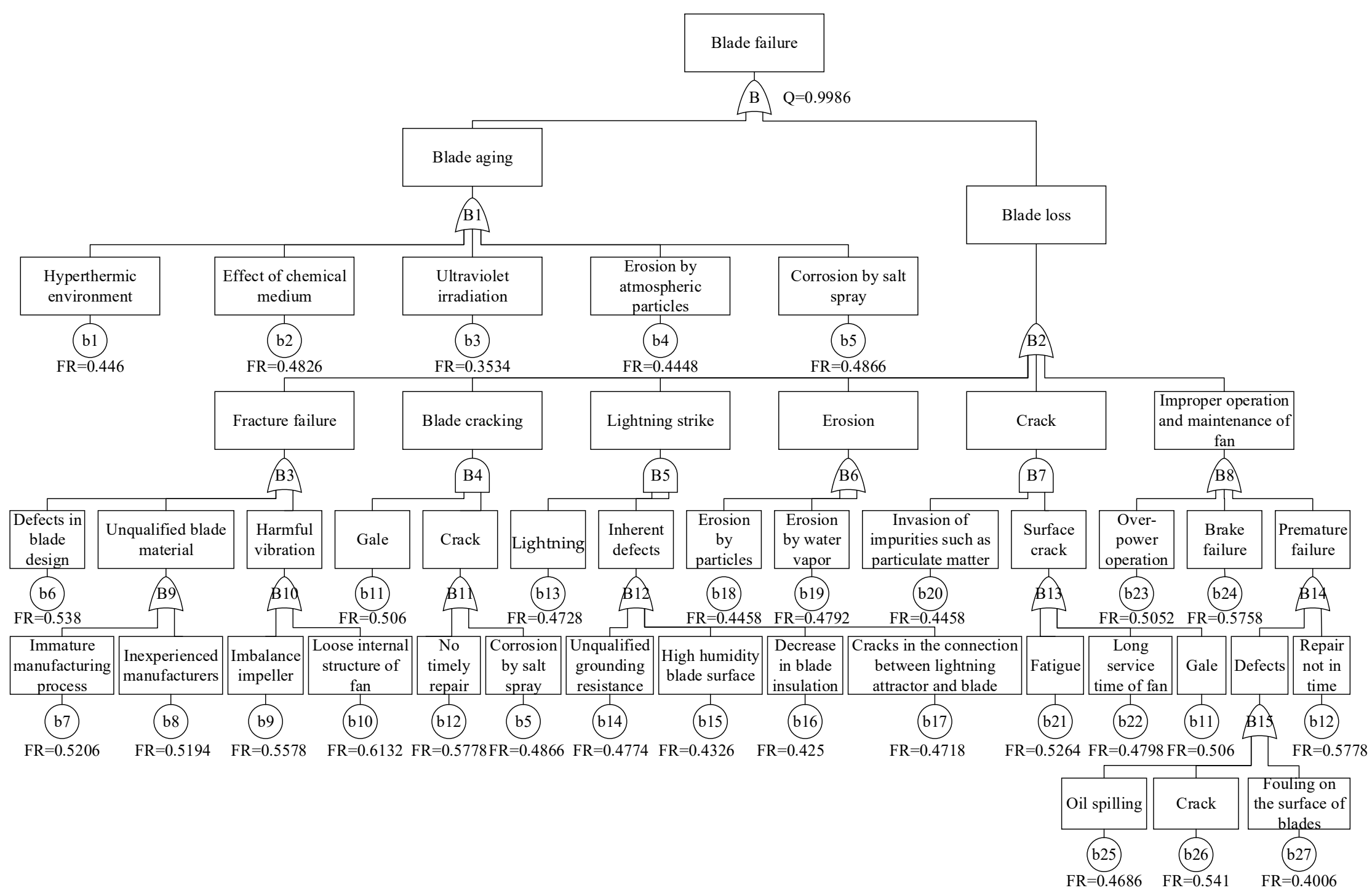

Figure 8. Fault tree analysis model for blade failure risk of the offshore wind farm. 


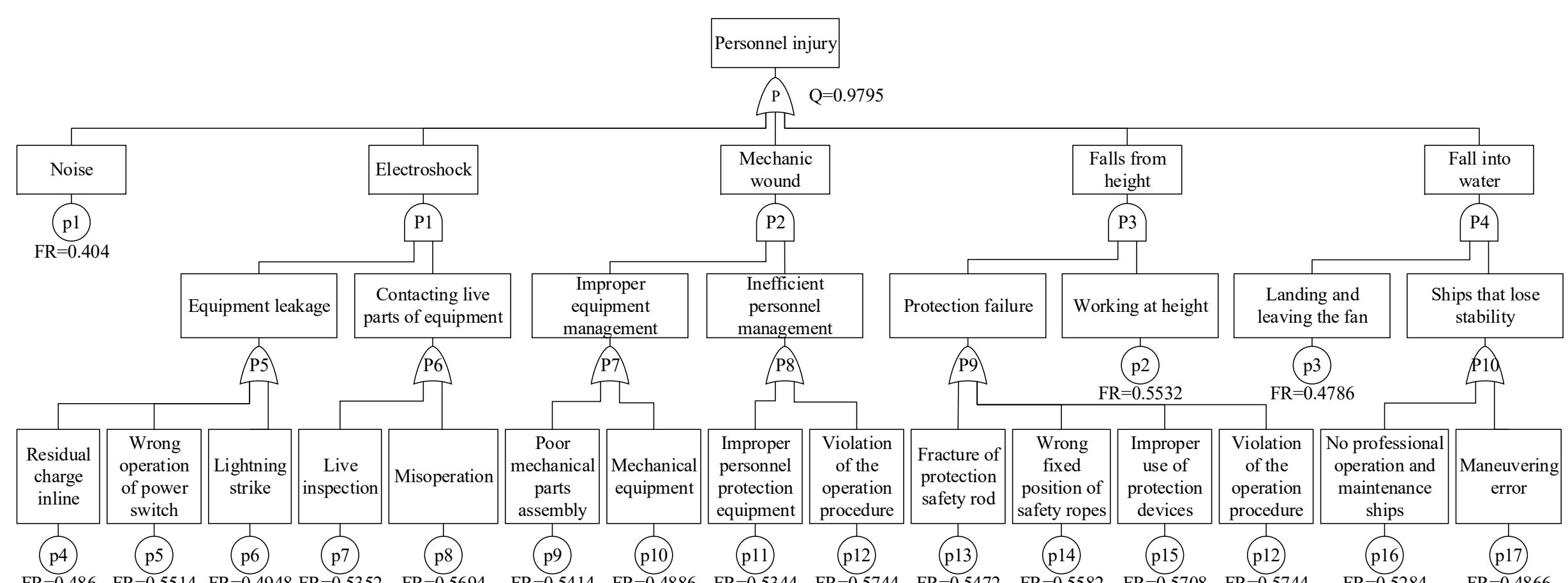

$\quad F R=0.486 \quad F R=0.5514 \quad F R=0.4948 \quad F R=0.5352 \quad F R=0.5694 \quad F R=0.5414 \quad F R=0.4886 \quad F R=0.5344 \quad F R=0.5744 \quad F R=0.5472 \quad F R=0.5582 \quad F R=0.5708 \quad F R=0.5744 \quad F R=0.5284 \quad F R=0.4866 \quad$

Figure 9. Fault tree analysis model for personnel injury risk of the offshore wind farm. 
Table 4. Lightning strike risk factors of offshore wind farms.

\begin{tabular}{ccc}
\hline Number & Risk Factor & Risk Index \\
\hline 11 & High average number of thunderstorm days & 0.4704 \\
12 & Poor contact between the flange of the tower and the electrode & 0.4658 \\
13 & Large device sizes & 0.3926 \\
14 & Salt spray & 0.4276 \\
15 & Widespread use and exposure of composite materials & 0.4106 \\
16 & No regular inspection of lightning protection facilities & 0.4898 \\
17 & Unreliable conductive pathway & 0.5494 \\
18 & Unqualified grounding resistance & 0.527 \\
19 & Limited thermal capacity of the grounding devices & 0.5182 \\
110 & Problems in grounding grid construction & 0.4678 \\
111 & Local corrosion of grounding devices & 0.4768 \\
112 & Poor design of lightning rod & 0.5388 \\
113 & Wrong location of the lightning rod & 0.5526 \\
\end{tabular}

Table 5. Blade failure risk factors of offshore wind farms.

\begin{tabular}{|c|c|c|}
\hline Number & Risk Factor & Risk Index \\
\hline b1 & Hyperthermic environment & 0.446 \\
\hline $\mathrm{b} 2$ & Effect of chemical medium & 0.4826 \\
\hline b3 & Ultraviolet irradiation & 0.3534 \\
\hline $\mathrm{b} 4$ & Erosion by atmospheric particles & 0.4448 \\
\hline b5 & Corrosion by salt spray & 0.4866 \\
\hline b6 & Defects in blade design & 0.538 \\
\hline b7 & Immature manufacturing processes & 0.5206 \\
\hline b8 & Inexperienced manufacturers & 0.5194 \\
\hline b9 & Imbalance impeller & 0.5578 \\
\hline b10 & Loose internal structure of fan & 0.6132 \\
\hline b11 & Gale & 0.506 \\
\hline b12 & No timely repair & 0.5778 \\
\hline b13 & Lightning & 0.4728 \\
\hline b14 & Unqualified grounding resistance & 0.4774 \\
\hline b15 & High humidity blade surface & 0.4326 \\
\hline b16 & Decrease in blade insulation & 0.425 \\
\hline b17 & Cracks in the connection between lightning attractor and blade & 0.4718 \\
\hline b18 & Erosion by particles & 0.4458 \\
\hline b19 & Erosion by water vapor & 0.4792 \\
\hline b20 & Invasion of impurities such as particulate matter & 0.4458 \\
\hline $\mathrm{b} 21$ & Fatigue & 0.4798 \\
\hline $\mathrm{b} 22$ & Long service time of fan & 0.5264 \\
\hline $\mathrm{b} 23$ & Over-power operation & 0.5052 \\
\hline b24 & Brake failure & 0.5758 \\
\hline $\mathrm{b} 25$ & Oil spilling & 0.4686 \\
\hline b26 & Crack & 0.541 \\
\hline $\mathrm{b} 27$ & Fouling on the surface of blades & 0.4006 \\
\hline
\end{tabular}

Table 6. Personnel injury risk factors of offshore wind farms.

\begin{tabular}{ccc}
\hline Number & Risk Factor & Risk Index \\
\hline p1 & Noise & 0.404 \\
p2 & Working at height & 0.5532 \\
p3 & Landing and leaving the fan & 0.4786 \\
p4 & Residual charge inline & 0.486 \\
p5 & Wrong operation of the power switch & 0.5514 \\
\hline
\end{tabular}


Table 6. Cont

\begin{tabular}{ccc}
\hline Number & Risk Factor & Risk Index \\
\hline p6 & Lightning strike & 0.4948 \\
p7 & Live inspection & 0.5352 \\
p8 & Misoperation & 0.5694 \\
p9 & Poor mechanical parts assembly & 0.5414 \\
p10 & Mechanical equipment & 0.4886 \\
p11 & Improper personnel protection equipment & 0.5344 \\
p12 & Violation of the operation procedure & 0.5744 \\
p13 & Fracture of protection safety rod & 0.5472 \\
p14 & Wrong fixed position of safety ropes & 0.5582 \\
p15 & Improper use of protection devices & 0.5708 \\
p16 & No professional operation and maintenance ships & 0.5286 \\
p17 & Maneuvering error & 0.4866 \\
\hline
\end{tabular}

\subsection{Risk Assessment}

(1) Risk assessment of fire

With the help of Isograph Reliability Workbench, the minimum cut set, structural importance degree, and probability importance degree of the fire accidents are presented underneath.

There are 28 minimum cut sets of fire accidents:

- Third-order minimum cut sets: $\{\mathrm{f} 1, \mathrm{f} 8, \mathrm{f} 17\},\{\mathrm{f} 1, \mathrm{f} 6, \mathrm{f} 17\},\{\mathrm{f} 1, \mathrm{f8}, \mathrm{f} 18\},\{\mathrm{f} 1, \mathrm{f} 2, \mathrm{f} 17\},\{\mathrm{f} 1, \mathrm{f} 9$, $\mathrm{f} 17\},\{\mathrm{f} 1, \mathrm{f} 10, \mathrm{f} 17\},\{\mathrm{f} 1, \mathrm{f} 13, \mathrm{f} 17\},\{\mathrm{f} 1, \mathrm{f} 6, \mathrm{f} 18\},\{\mathrm{f} 1, \mathrm{f} 2, \mathrm{f} 18\},\{\mathrm{f} 1, \mathrm{f} 14, \mathrm{f} 17\},\{\mathrm{f} 1, \mathrm{f} 9, \mathrm{f} 18\},\{\mathrm{f} 1, \mathrm{f} 5$, $f 17\},\{f 1, f 10, f 18\},\{f 1, f 13, f 18\},\{f 1, f 7, f 17\},\{f 1, f 3, f 17\},\{f 1, f 14, f 18\},\{f 1, f 5, f 18\},\{f 1$,

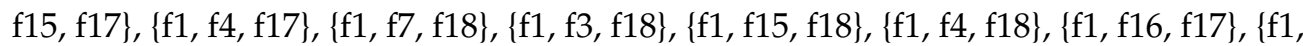
f16, f18\};

- Fourth-order minimum cut sets: $\{\mathrm{f} 1, \mathrm{f} 11, \mathrm{f} 12, \mathrm{f} 17\},\{\mathrm{f} 1, \mathrm{f} 11, \mathrm{f} 12, \mathrm{f} 18\}$.

The structural importance degree of fire accidents is as follows:

$\mathrm{I}(\mathrm{f} 1)>\mathrm{I}(\mathrm{f} 18)=\mathrm{I}(\mathrm{f} 17)>\mathrm{I}(\mathrm{f} 16)=\mathrm{I}(\mathrm{f} 15)=\mathrm{I}(\mathrm{f} 14)=\mathrm{I}(\mathrm{f} 13)=\mathrm{I}(\mathrm{f} 10)=\mathrm{I}(\mathrm{f} 9)=\mathrm{If} 8)=\mathrm{I}(\mathrm{f} 7)=\mathrm{I}(\mathrm{f} 6)$ $=\mathrm{I}(\mathrm{f} 5)=\mathrm{I}(\mathrm{f} 4)=\mathrm{I}(\mathrm{f} 3)=\mathrm{I}(\mathrm{f} 2)>\mathrm{I}(\mathrm{f} 12)=\mathrm{I}(\mathrm{f} 11)$.

The Fussell-Vesely Importance of the basic events of wind turbine fire in offshore wind farms is shown in Figure 10. The order of probability importance is listed as follows:

Fire

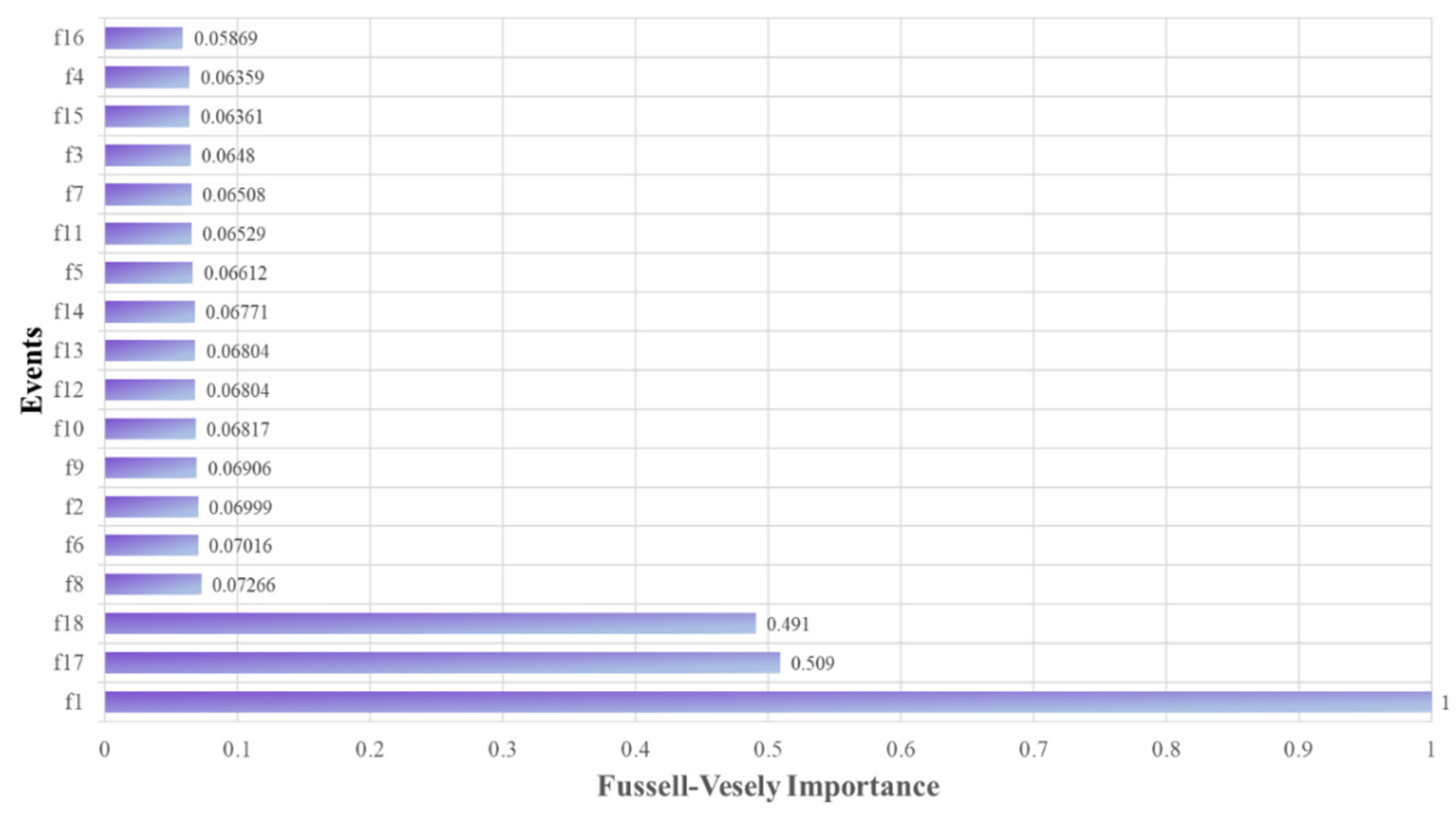

Figure 10. Fussell-Vesely Importance of each basic event of the fire accident. 
Improper fire stopping methods(f1) $>$ Oil leakage(f17) $>$ Oily cotton and other materials(f18) $>$ Violation of safety regulations(f8) $>$ Overload(f6) $>$ Lightning strike(f2) $>$ Improper selection and installation of electrical devices(f9) $>$ Irrational design of electrical circuit(f10) $>$ Overspeed(f13) $>$ Mechanical friction(f14) $>$ Salt spray corrosion(f5) $>$ Vulnerabilities in device's manufacturing(f7) $>$ Improper electrical operation(f3) $>$ Increases Electrical contact resistance(f15) $>$ Mechanical damage to electrical devices(f4) $>$ Poor ventilation(f16) $>$ Small space(f12) $>$ Welding(f11).

(2) Risk assessment of lightning

With the help of Isograph Reliability Workbench, the minimum cut set, structural importance degree, and probability importance degree of the lightning accidents are presented underneath.

There are 45 minimum cut sets of lightning accidents:

- Second-order minimum cut sets: $\{11,113\},\{11,17\},\{12,113\},\{12,17\},\{11,112\},\{12,112\},\{11$, $18\},\{12,18\},\{11,19\},\{12,19\},\{14,113\},\{14,17\},\{11,114\},\{12,114\},\{11,16\},\{14,112\},\{12,16\},\{15$, $113\},\{14,18\},\{11,111\},\{15,17\},\{12,111\},\{14,19\},\{11,110\},\{15,112\},\{12,110\},\{15,18\},\{13,113\}$, $\{13,17\},\{14,114\},\{15,19\},\{13,112\},\{14,16\},\{13,18\},\{14,111\},\{15,114\},\{13,19\},\{15,16\},\{14,110\}$, $\{15,111\},\{13,114\},\{15,110\},\{13,16\},\{13,111\},\{13,110\}$.

The structural importance degree of lightning accidents is as follows:

$\mathrm{I}(15)=\mathrm{I}(14)=\mathrm{I}(13)=\mathrm{I}(12)=\mathrm{I}(11)>\mathrm{I}(114)=\mathrm{I}(113)=\mathrm{I}(112)=\mathrm{I}(111)=\mathrm{I}(110)=\mathrm{I}(19)=\mathrm{I}(18)=$ $\mathrm{I}(17)=\mathrm{I}(16)$.

The Fussell-Vesely Importance of the basic events of wind turbine lightning in offshore wind farms is shown in Figure 11. The order of probability importance is as follows:

\section{Lightning}

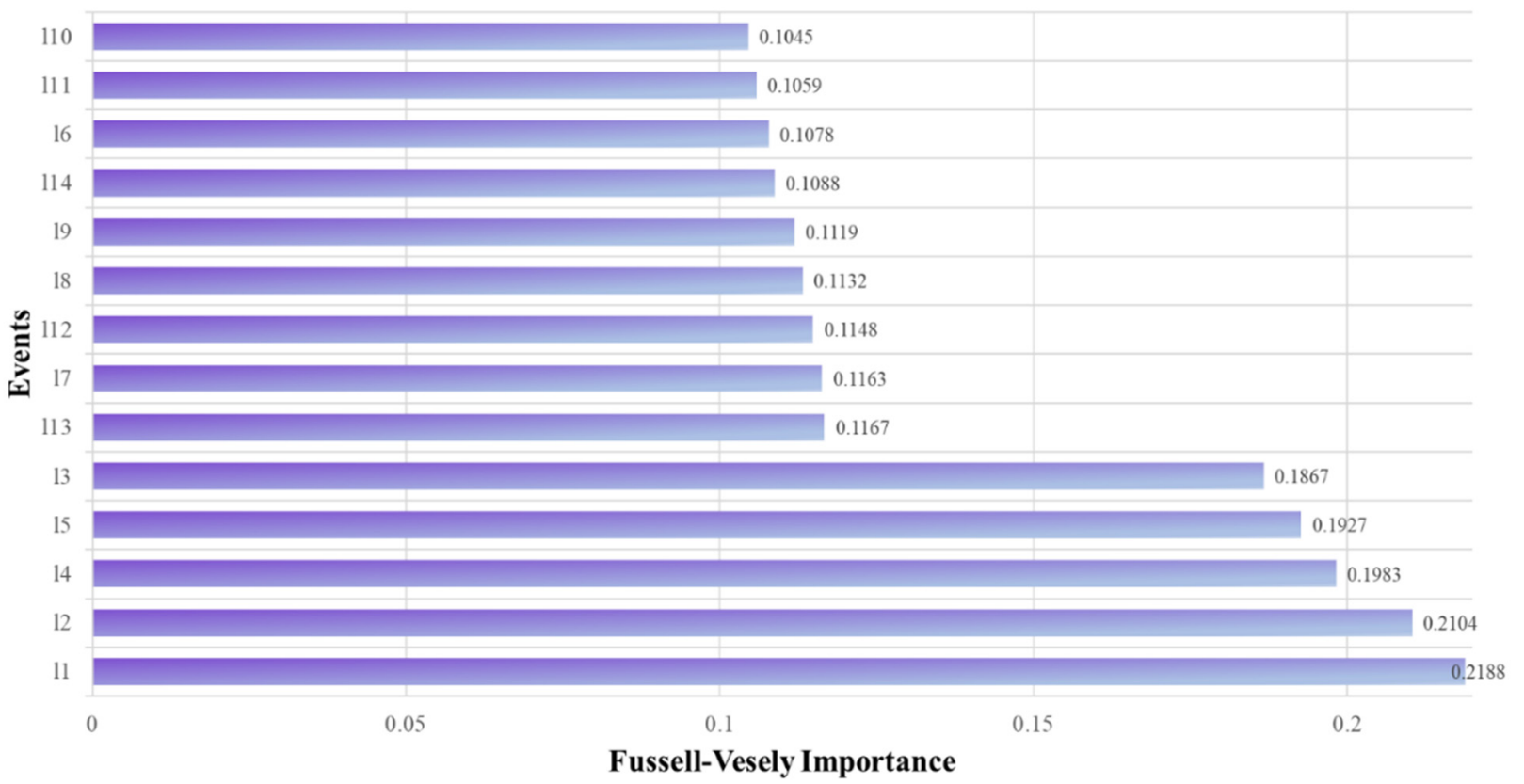

Figure 11. Fussell-Vesely Importance of each basic event of a lightning accident.

High average number of thunderstorm days(11) > Poor contact between the flange of the tower and the electrode point $(12)>$ salt spray $(14)>$ Widespread use and exposure of composite materials(15) $>$ Large device sizes(13) $>$ Wrong location of the lightning $\operatorname{rod}(113)$ $>$ Unreliable conductive pathway(17) $>$ Poor design of lightning $\operatorname{rod}(112)>$ Unqualified grounding resistance(18) $>$ Limited thermal capacity of the grounding devices(19) $>$ Errors in design of equalizing network(114) $>$ No regular inspection of lightning protection facilities(16) > Local corrosion of grounding devices(111) > Problems in grounding grid construction(110). 
(3) Risk assessment of blade failure

With the help of Isograph Reliability Workbench, the minimum cut set, structural importance degree, and probability importance degree of the blade failure accidents are presented underneath.

There are 24 minimum cut sets of blade failure accidents:

- First-order minimum cut sets are as follows: $\{b 10\},\{b 24\},\{b 9\},\{b 6\},\{b 7\},\{b 8\},\{b 23\}$, $\{b 5\},\{b 2\},\{b 19\},\{b 1\},\{b 18\},\{b 4\},\{b 3\},\{b 25\},\{b 26\},\{b 27\}$;

- Second-order minimum cut sets are $\{b 12, b 26\},\{b 12, b 25\},\{b 22, b 20\},\{b 12, b 27\},\{b 13$, b14 $\},\{b 11, b 20\},\{b 13, b 17\},\{b 21, b 20\},\{b 13, b 15\},\{b 13, b 16\}$.

The structural importance degree of blade failure accidents is as follows:

$\mathrm{I}(\mathrm{b} 24)=\mathrm{I}(\mathrm{b} 23)=\mathrm{I}(\mathrm{b} 22)=\mathrm{I}(\mathrm{b} 21)=\mathrm{I}(\mathrm{b} 20)=\mathrm{I}(\mathrm{b} 19)=\mathrm{I}(\mathrm{b} 18)=\mathrm{I}(\mathrm{b} 11)=\mathrm{I}(\mathrm{b} 10)=\mathrm{I}(\mathrm{b} 9)=\mathrm{I}(\mathrm{b} 8)$ $=\mathrm{I}(\mathrm{b} 7)=\mathrm{I}(\mathrm{b} 6)=\mathrm{I}(\mathrm{b} 5)=\mathrm{I}(\mathrm{b} 4)=\mathrm{I}(\mathrm{b} 3)=\mathrm{I}(\mathrm{b} 2)=\mathrm{I}(\mathrm{b} 1)>\mathrm{I}(\mathrm{b} 13)>\mathrm{I}(\mathrm{b} 12)>\mathrm{I}(\mathrm{b} 27)=\mathrm{I}(\mathrm{b} 26)=\mathrm{I}(\mathrm{b} 25)$ $>\mathrm{I}(\mathrm{b} 17)=\mathrm{I}(\mathrm{b} 16)=\mathrm{I}(\mathrm{b} 15)=\mathrm{I}(\mathrm{b} 14)$.

The Fussell-Vesely Importance of the basic events of wind turbine blade failure in offshore wind farms is shown in Figure 12. The order of probability importance is listed as follows:

\section{Blade Failure}

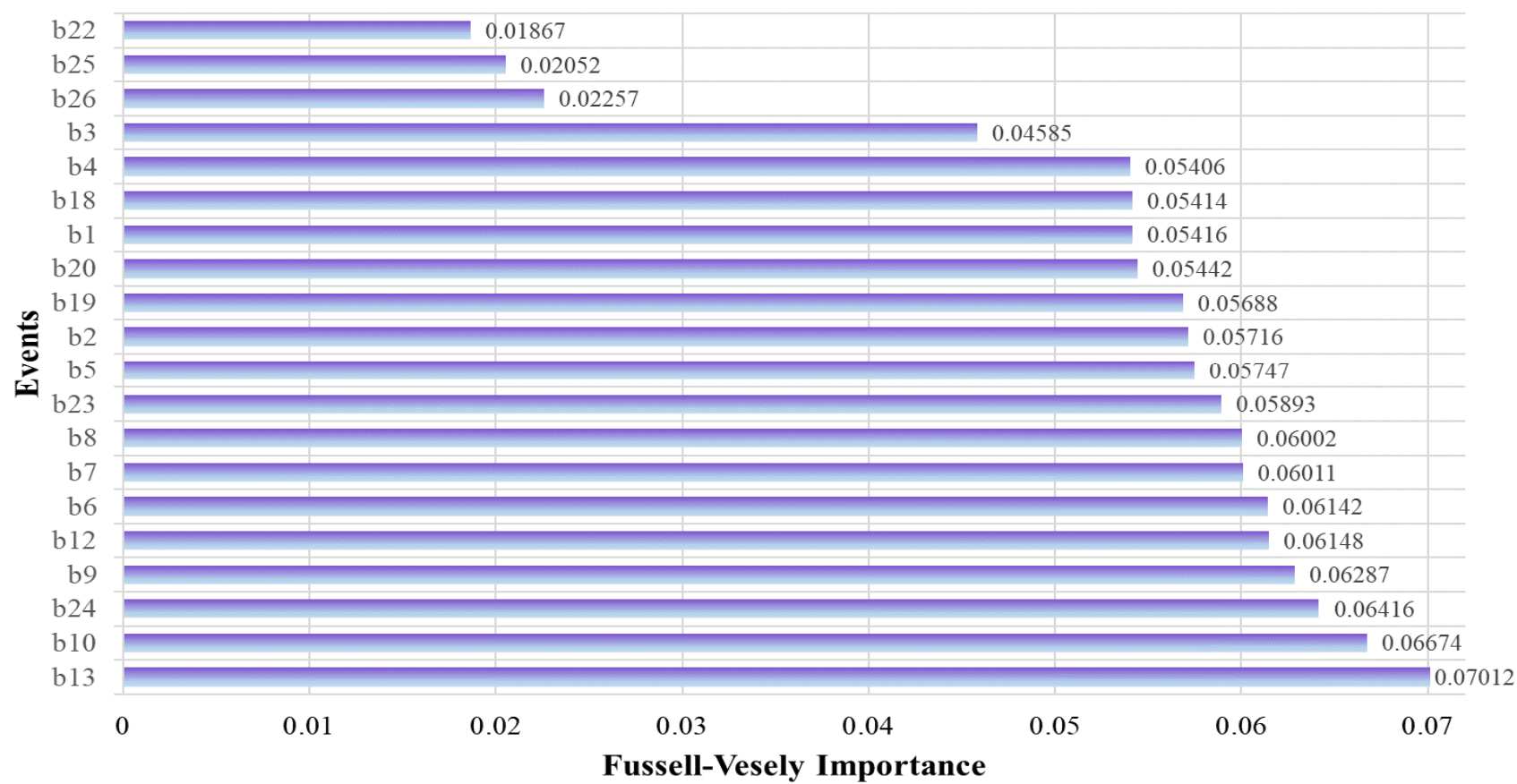

Figure 12. Fussell-Vesely Importance of each basic event of blade failure accident (The event whose Fussell-Vesely importance degree is less than 0.01867 is ignored).

Lightning(b13) > Loose internal structure of $f a n(b 10)>$ Brake failure $(b 24)>$ Imbalance impeller(b9) $>$ No timely repair(b12) > Defects in blade design(b6) > Immature manufacturing processes $(\mathrm{b} 7)>$ Inexperienced manufacturers $(\mathrm{b} 8)>$ Over-power operation $(\mathrm{b} 23)>$ Corrosion by salt spray(b5) $>$ Effect of chemical medium(b2) $>$ Erosion by water vapor(b19) $>$ Invasion of impurities such as particulate matter(b20) $>$ Hyperthermic environment(b1) $>$ Erosion by particles(b18) $>$ Erosion by atmospheric particles(b4) > Ultraviolet irradiation(b3) > Crack(b26) > Oil spilling(b25) > Long service time of fan(b22).

(4) Risk assessment of personnel injury

With the help of Isograph Reliability Workbench, the minimum cut set, structural importance degree, and probability importance degree of the personnel injury accidents are presented underneath.

There are 17 minimum cut sets of personnel injury accidents: 
- First-order minimum cut set is as follows: $\{p 1\}$;

- Second-order minimum cut sets are as follows: $\{\mathrm{p} 12, \mathrm{p} 2\},\{\mathrm{p} 15, \mathrm{p} 2\},\{\mathrm{p} 5, \mathrm{p} 8\},\{\mathrm{p} 12, \mathrm{p} 9\}$, $\{\mathrm{p} 14, \mathrm{p} 2\},\{\mathrm{p} 13, \mathrm{p} 2\},\{\mathrm{p} 5, \mathrm{p} 7\},\{\mathrm{p} 11, \mathrm{p} 9\},\{\mathrm{p} 6, \mathrm{p} 8\},\{\mathrm{p} 12, \mathrm{p} 10\},\{\mathrm{p} 4, \mathrm{p} 8\},\{\mathrm{p} 6, \mathrm{p} 7\},\{\mathrm{p} 11, \mathrm{p} 10\}$, $\{\mathrm{p} 4, \mathrm{p} 7\},\{\mathrm{p} 3, \mathrm{p} 17\},\{\mathrm{p} 3, \mathrm{p} 18\}$.

The structural importance degree of personnel injury accidents is as follows:

$\mathrm{I}(\mathrm{p} 1)>\mathrm{I}(\mathrm{p} 2)>\mathrm{I}(\mathrm{p} 8)=\mathrm{I}(\mathrm{p} 7)=\mathrm{I}(\mathrm{p} 3)>\mathrm{I}(\mathrm{p} 12)>\mathrm{I}(\mathrm{p} 11)>\mathrm{I}(\mathrm{p} 10)=\mathrm{I}(\mathrm{p} 9)>\mathrm{I}(\mathrm{p} 17)=\mathrm{I}(\mathrm{p} 16)=$ $\mathrm{I}(\mathrm{p} 6)=\mathrm{I}(\mathrm{p} 5)=\mathrm{I}(\mathrm{p} 4)>\mathrm{I}(\mathrm{p} 15)=\mathrm{I}(\mathrm{p} 14)=\mathrm{I}(\mathrm{p} 13)$.

The Fussell-Vesely Importance of the basic event of wind turbine personnel injury in offshore wind farms is shown in Figure 13. Thus, the order of probability importance is as follows:

\section{Personnel Injury}

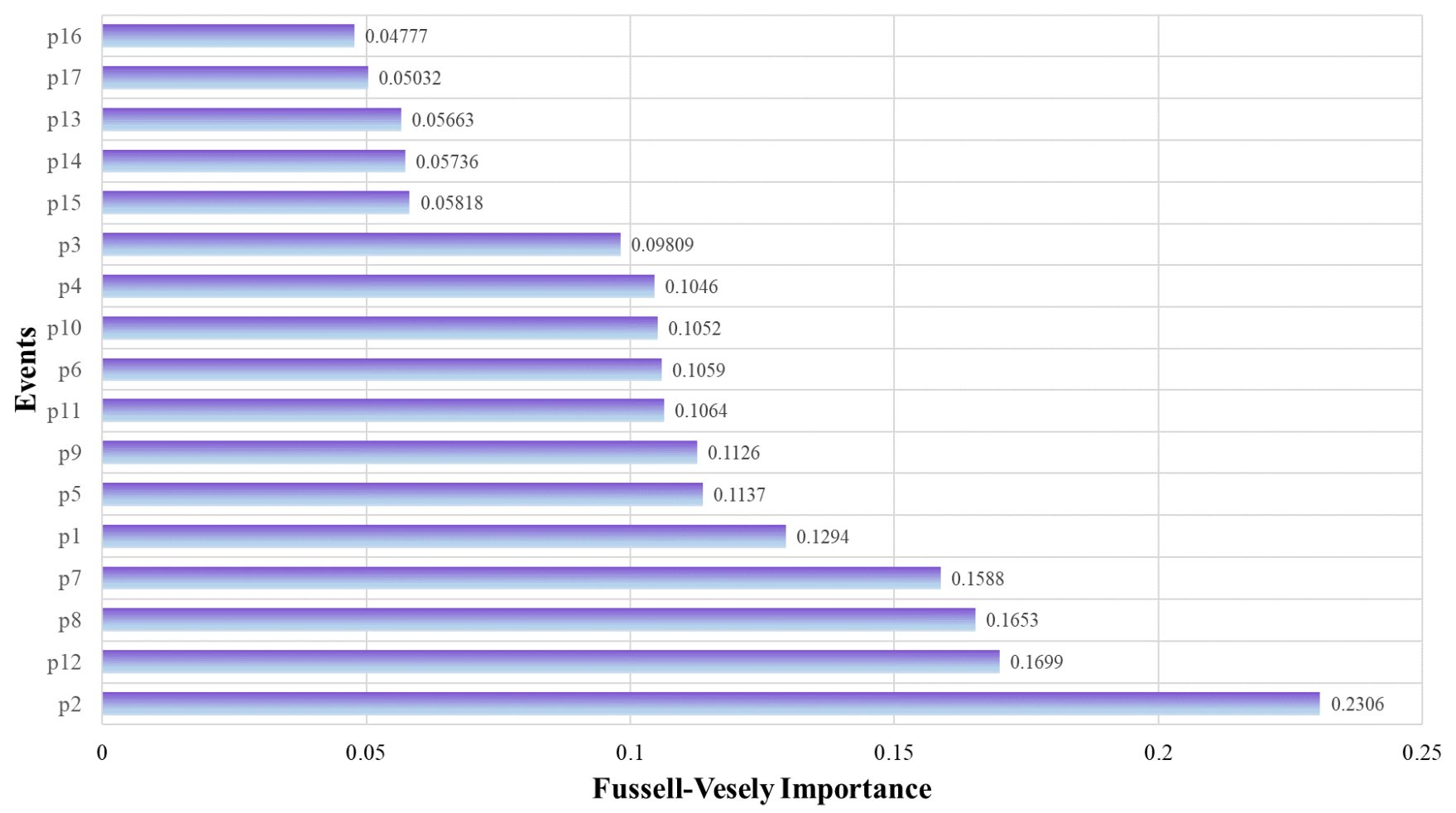

Figure 13. Fussell-Vesely Importance of each basic event of personnel injury accident.

Working at height $(\mathrm{p} 2)>$ Violation of the operation procedure $(\mathrm{p} 12)>$ Misoperation(p8) $>$ Live inspection $(\mathrm{p} 7)>$ Noise $(\mathrm{p} 1)>$ Wrong operation of power switch $(\mathrm{p} 14)>$ Poor mechanical parts assembly $(\mathrm{p} 9)>$ Improper personnel protection equipment $(\mathrm{p} 11)>$ Lightning strike(p6) > Mechanical equipment(p10) $>$ Residual charge inline(p4) $>$ Landing and leaving the fan(p3) $>$ Improper use of protection devices(p15) $>$ Wrong fixed position of safety ropes(p14) $>$ Fracture of protection safety $\operatorname{rod}(\mathrm{p} 13)>$ No professional operation and maintenance ships(p16) > Maneuvering error(p17).

\section{Navigation Risks of Wind Farm Waters}

\subsection{Fault Tree for Navigation Risk}

This section describes the fault tree analysis of collision (see Figure 14) and submarine cable (see Figure 15). 


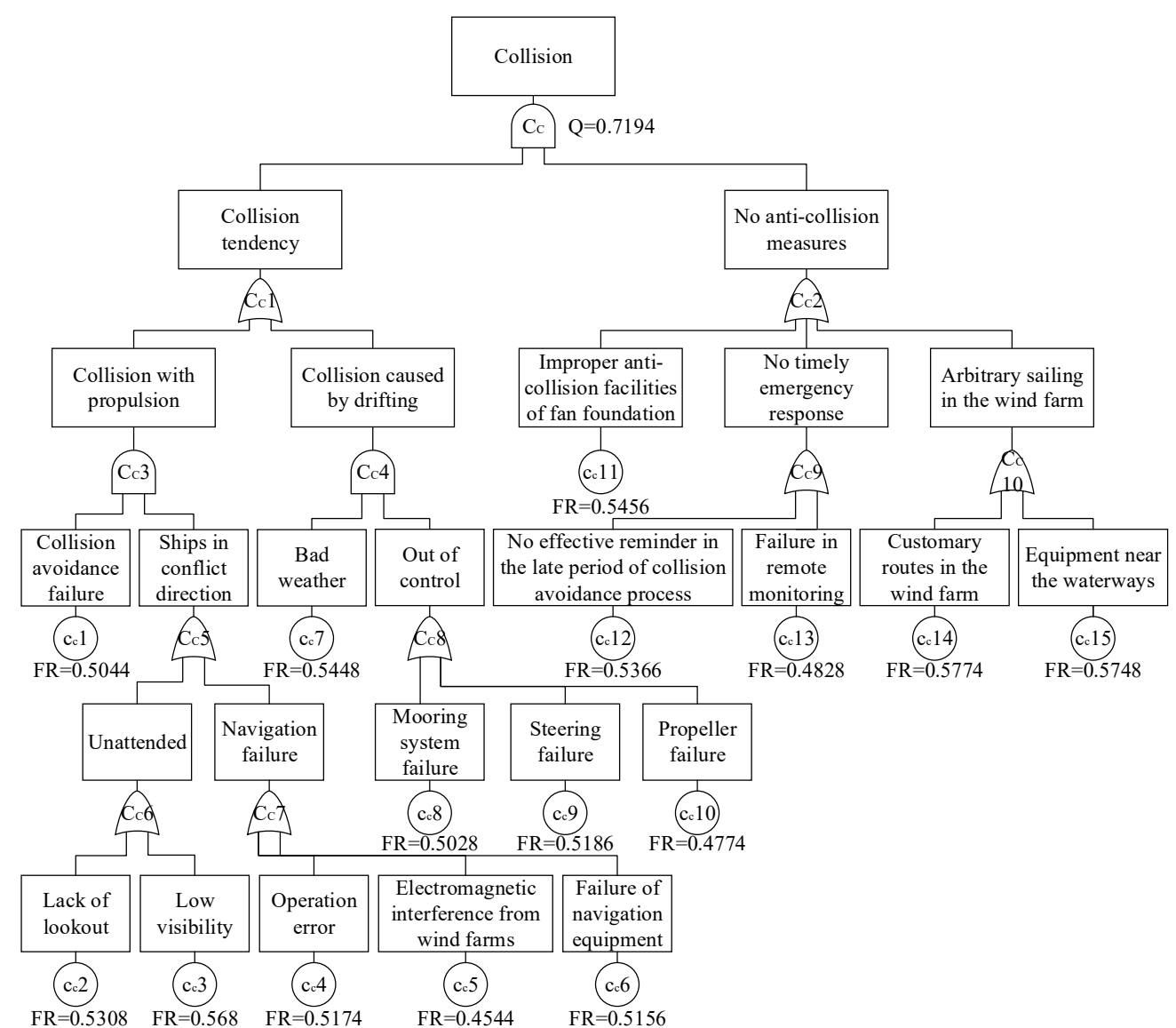

Figure 14. Fault tree analysis model for collision risk of the offshore wind farm.

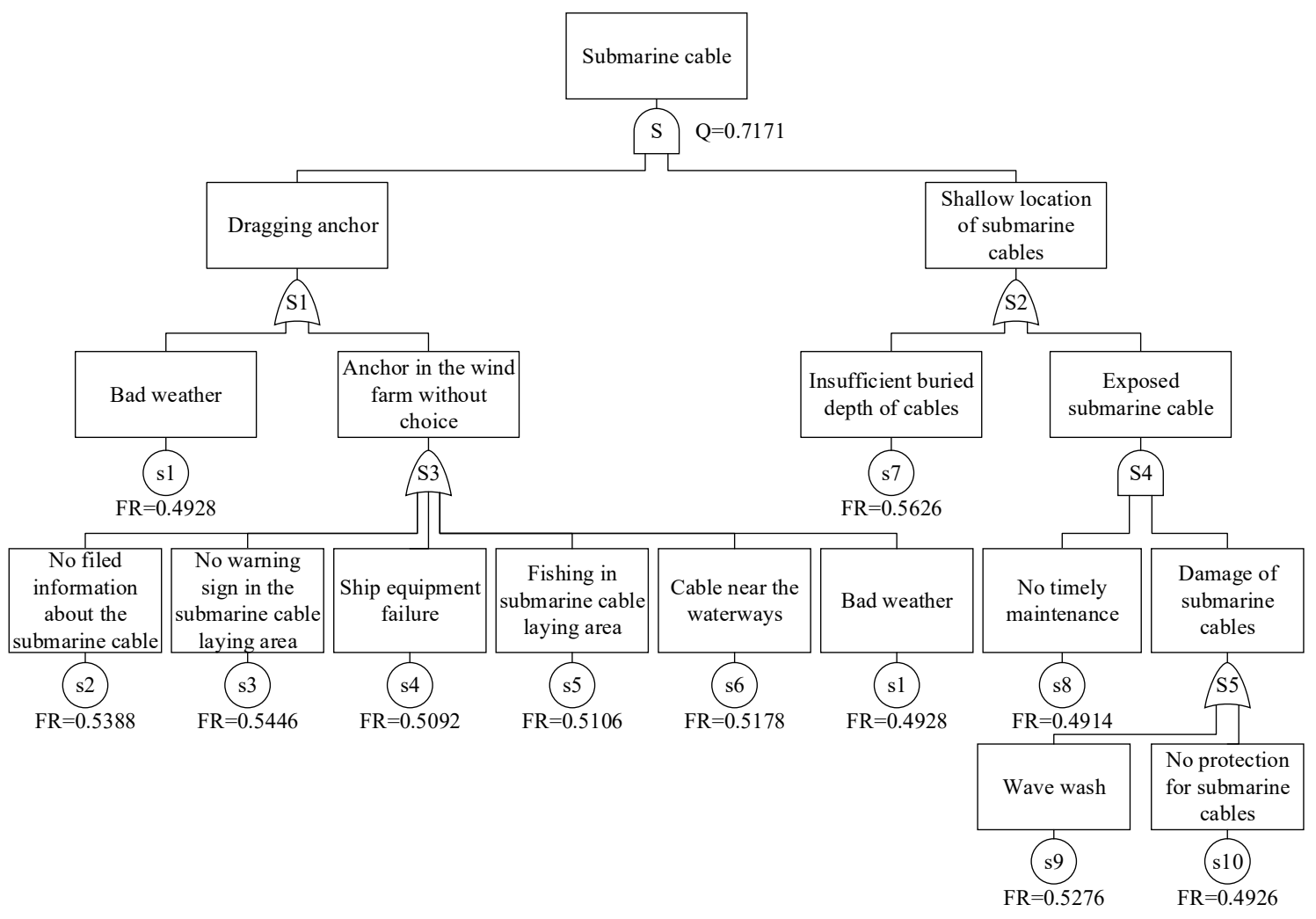

Figure 15. Fault tree analysis model for submarine cable risk of the offshore wind farm. 


\subsection{Risk Index of the Basic Events}

According to the questionnaires, the risk index of the basic events in the fault tree for collision and submarine cable are provided in Tables 7 and 8.

Table 7. Collision risk factors of offshore wind farms.

\begin{tabular}{|c|c|c|}
\hline Number & Risk Factor & Risk Index \\
\hline$c_{C} 1$ & Collision avoidance failure & 0.5044 \\
\hline$c_{C}^{2}$ & Lack of lookout & 0.5308 \\
\hline$c_{C} 3$ & Low visibility & 0.568 \\
\hline$c_{C} 4$ & Operation error & 0.5174 \\
\hline$c_{C} 5$ & Electromagnetic interference from wind farms & 0.4544 \\
\hline$c_{C} 6$ & Failure of navigation equipment & 0.5156 \\
\hline $\mathrm{c}_{\mathrm{C}} 7$ & Bad weather & 0.5448 \\
\hline $\mathrm{c}_{\mathrm{C}} 8$ & Mooring system failure & 0.5028 \\
\hline$c_{C} 9$ & Steering failure & 0.5186 \\
\hline$c_{C} 10$ & Propeller failure & 0.4774 \\
\hline$c_{C} 11$ & Improper anti-collision facilities of fan foundation & 0.5456 \\
\hline $\mathrm{c}_{\mathrm{C}} 12$ & No effective reminder in the late period of the collision avoidance process & 0.5366 \\
\hline $\mathrm{c}_{\mathrm{C}} 13$ & Failure in remote monitoring & 0.4828 \\
\hline$c_{C} 14$ & Customary routes in the wind farm & 0.5774 \\
\hline $\mathrm{c}_{\mathrm{C}} 15$ & Equipment near the waterways & 0.5748 \\
\hline
\end{tabular}

Table 8. Submarine cables' risk factors of offshore wind farms.

\begin{tabular}{ccc}
\hline Number & Risk Factor & Risk Index \\
\hline s1 & Bad weather & 0.4928 \\
s2 & No filed information about the submarine cable & 0.5388 \\
s3 & No warning sign in the submarine cable laying area & 0.5446 \\
s4 & Ship equipment failure & 0.5092 \\
s5 & Fishing in submarine cable laying area & 0.5106 \\
s6 & Cable near the waterways & 0.5178 \\
s7 & Insufficient buried depth of cables & 0.5626 \\
s8 & No timely maintenance & 0.4914 \\
s9 & Wave wash & 0.5276 \\
s10 & No protection for submarine cables & 0.4126 \\
\hline
\end{tabular}

\subsection{Risk Assessment}

(1) Risk assessment of collision

With the help of Isograph Reliability Workbench, the minimum cut set, structural importance degree, and probability importance degree of the collision accidents are presented underneath.

There are 40 minimum cut sets of collision accidents:

- Third-order minimum cut sets: $\left\{c_{C} 1, c_{C} 3, c_{C} 14\right\},\left\{c_{C} 1, c_{C} 3, c_{C} 15\right\},\left\{c_{C} 7, c_{C} 9, c_{C} 14\right\}$, $\left\{c_{C} 7, c_{C} 9, c_{C} 15\right\},\left\{c_{C} 7, c_{C} 8, c_{C} 14\right\},\left\{c_{C} 7, c_{C} 8, c_{C} 15\right\},\left\{c_{C} 1, c_{C} 3, c_{C} 11\right\},\left\{c_{C} 1, c_{C} 2, c_{C} 14\right\}$, $\left\{c_{C} 7, c_{C} 9, c_{C} 11\right\},\left\{c_{C} 1, c_{C} 2, c_{C} 15\right\},\left\{c_{C} 1, c_{C} 3, c_{C} 12\right\},\left\{c_{C} 7, c_{C} 9, c_{C} 12\right\},\left\{c_{C} 1, c_{C} 4, c_{C} 14\right\}$, $\left\{c_{C} 1, c_{C} 6, c_{C} 14\right\},\left\{c_{C} 1, c_{C} 4, c_{C} 15\right\},\left\{c_{C} 7, c_{C} 10, c_{C} 14\right\},\left\{c_{C} 1, c_{C} 6, c_{C} 15\right\},\left\{c_{C} 7, c_{C} 8, c_{C} 11\right\}$, $\left\{\mathrm{c}_{C} 7, \mathrm{c}_{\mathrm{C}} 10, \mathrm{c}_{\mathrm{C}} 15\right\},\left\{\mathrm{c}_{\mathrm{C}} 7, \mathrm{c}_{\mathrm{C}} 8, \mathrm{c}_{\mathrm{C}} 12\right\},\left\{\mathrm{c}_{\mathrm{C}} 1, \mathrm{c}_{\mathrm{C}} 2, \mathrm{c}_{\mathrm{C}} 11\right\},\left\{\mathrm{c}_{\mathrm{C}} 1, \mathrm{c}_{\mathrm{C}} 2, \mathrm{c}_{\mathrm{C}} 12\right\},\left\{\mathrm{c}_{\mathrm{C}} 1, \mathrm{c}_{\mathrm{C}} 4, \mathrm{c}_{\mathrm{C}} 11\right\}$, $\left\{c_{C} 1, c_{C} 6, c_{C} 11\right\},\left\{c_{C} 7, c_{C} 10, c_{C} 11\right\},\left\{c_{C} 1, c_{C} 4, c_{C} 12\right\},\left\{c_{C} 1, c_{C} 6, c_{C} 12\right\},\left\{c_{C} 7, c_{C} 10, c_{C} 12\right\}$, $\left\{c_{C} 1, c_{C} 3, c_{C} 13\right\},\left\{c_{C} 7, c_{C} 9, c_{C} 13\right\},\left\{c_{C} 7, c_{C} 8, c_{C} 13\right\},\left\{c_{C} 1, c_{C} 5, c_{C} 14\right\},\left\{c_{C} 1, c_{C} 5, c_{C} 15\right\}$, $\left\{c_{C} 1, c_{C} 2, c_{C} 13\right\},\left\{c_{C} 1, c_{C} 4, c_{C} 13\right\},\left\{c_{C} 1, c_{C} 6, c_{C} 13\right\},\left\{c_{C} 7, c_{C} 10, c_{C} 13\right\},\left\{c_{C} 1, c_{C} 5, c_{C} 11\right\}$, $\left\{c_{C} 1, c_{C} 5, c_{C} 12\right\},\left\{c_{C} 1, c_{C} 5, c_{C} 13\right\}$.

The structural importance degree of collision accidents is as follows:

$\mathrm{I}\left(\mathrm{c}_{C} 1\right)>\mathrm{I}\left(\mathrm{c}_{\mathrm{C}} 7\right)>\mathrm{I}\left(\mathrm{c}_{\mathrm{C}} 10\right)=\mathrm{I}\left(\mathrm{c}_{\mathrm{C}} 9\right)=\mathrm{I}\left(\mathrm{c}_{\mathrm{C}} 8\right)>\mathrm{I}\left(\mathrm{c}_{\mathrm{C}} 15\right)=\mathrm{I}\left(\mathrm{c}_{\mathrm{C}} 14\right)=\mathrm{I}\left(\mathrm{c}_{\mathrm{C}} 13\right)=\mathrm{I}\left(\mathrm{c}_{\mathrm{C}} 12\right)=\mathrm{I}\left(\mathrm{c}_{\mathrm{C}} 11\right)$ $>\mathrm{I}\left(\mathrm{c}_{\mathrm{C}} 6\right)=\mathrm{I}\left(\mathrm{c}_{\mathrm{C}} 5\right)=\mathrm{I}\left(\mathrm{c}_{\mathrm{C}} 4\right)=\mathrm{I}\left(\mathrm{c}_{\mathrm{C}} 3\right)=\mathrm{I}\left(\mathrm{c}_{\mathrm{C}} 2\right)$. 
The Fussell-Vesely Importance of the basic event of wind turbine collision in offshore wind farms is shown in Figure 16. The order of probability importance is listed as follows:

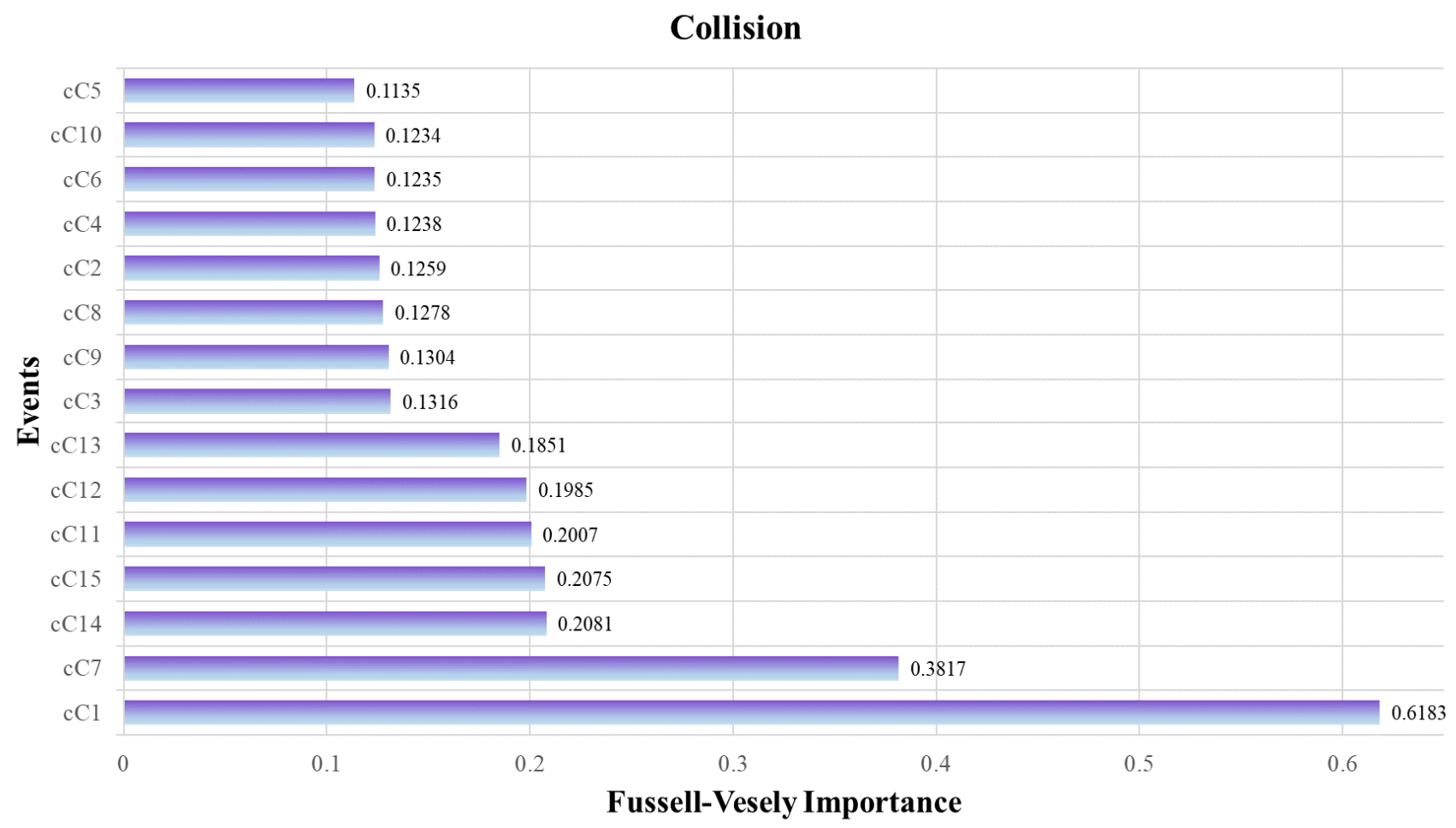

Figure 16. Fussell-Vesely Importance of each basic event of a collision accident.

Collision avoidance failure $\left(c_{C} 1\right)>$ Bad weather $\left(c_{C} 7\right)>$ Customary routes in the wind farm $\left(c_{C} 14\right)>$ Equipment near the waterways $\left(c_{C} 15\right)>$ Improper anti-collision facilities of fan foundation $\left(c_{C} 11\right)>$ No effective reminder in the late period of collision avoidance process $\left(c_{C} 12\right)>$ Failure in remote monitoring $\left(c_{C} 13\right)>$ Low visibility $\left(c_{C} 3\right)>$ Steering failure $\left(c_{C} 9\right)>$ Mooring system failure $\left(c_{C} 8\right)>$ Lack of lookout $\left(c_{C} 2\right)>$ Operation error $\left(c_{C} 4\right)>$ Failure of navigation equipment $\left(c_{C} 6\right)>$ Propeller failure $\left(c_{C} 10\right)>$ Electromagnetic interference from wind farms $\left(c_{C} 5\right)$.

(2) Risk assessment of submarine cable

With the help of Isograph Reliability Workbench, the minimum cut set, structural importance degree, and probability importance degree of the submarine cable accidents are presented underneath.

There are 18 minimum cut sets of submarine cable accidents:

- $\quad$ Second-order minimum cut sets: $\{s 3, s 7\},\{s 2, s 7\},\{s 6, s 7\},\{s 5, s 7\},\{s 4, s 7\},\{s 1, s 7\}$;

- Third-order minimum cut sets: $\{\mathrm{s} 3, \mathrm{~s} 8, \mathrm{~s} 9\},\{\mathrm{s} 2, \mathrm{~s} 8, \mathrm{~s} 9\},\{\mathrm{s} 6, \mathrm{~s} 8, \mathrm{~s} 9\},\{\mathrm{s} 5, \mathrm{~s} 8, \mathrm{~s} 9\},\{\mathrm{s} 4, \mathrm{~s} 8, \mathrm{~s} 9\}$, $\{\mathrm{s} 3, \mathrm{~s} 8, \mathrm{~s} 10\},\{\mathrm{s} 2, \mathrm{~s} 8, \mathrm{~s} 10\},\{\mathrm{s} 1, \mathrm{~s} 8, \mathrm{~s} 9\},\{\mathrm{s} 6, \mathrm{~s} 8, \mathrm{~s} 10\},\{\mathrm{s} 5, \mathrm{~s} 8, \mathrm{~s} 10\},\{\mathrm{s} 4, \mathrm{~s} 8, \mathrm{~s} 10\},\{\mathrm{s} 1, \mathrm{~s} 8, \mathrm{~s} 10\}$.

The structural importance degree of submarine cable accidents is as follows:

$\mathrm{I}(\mathrm{s} 7)>\mathrm{I}(\mathrm{s} 8)>\mathrm{I}(\mathrm{s} 10)=\mathrm{I}(\mathrm{s} 9)>\mathrm{I}(\mathrm{s} 6)=\mathrm{I}(\mathrm{s} 5)=\mathrm{I}(\mathrm{s} 4)=\mathrm{I}(\mathrm{s} 3)=\mathrm{I}(\mathrm{s} 2)=\mathrm{I}(\mathrm{s} 1)$.

The Fussell-Vesely Importance of the basic event of submarine cable in offshore wind farms is shown in Figure 17. The order of probability importance is listed as follows: 


\section{Submarine Cable}

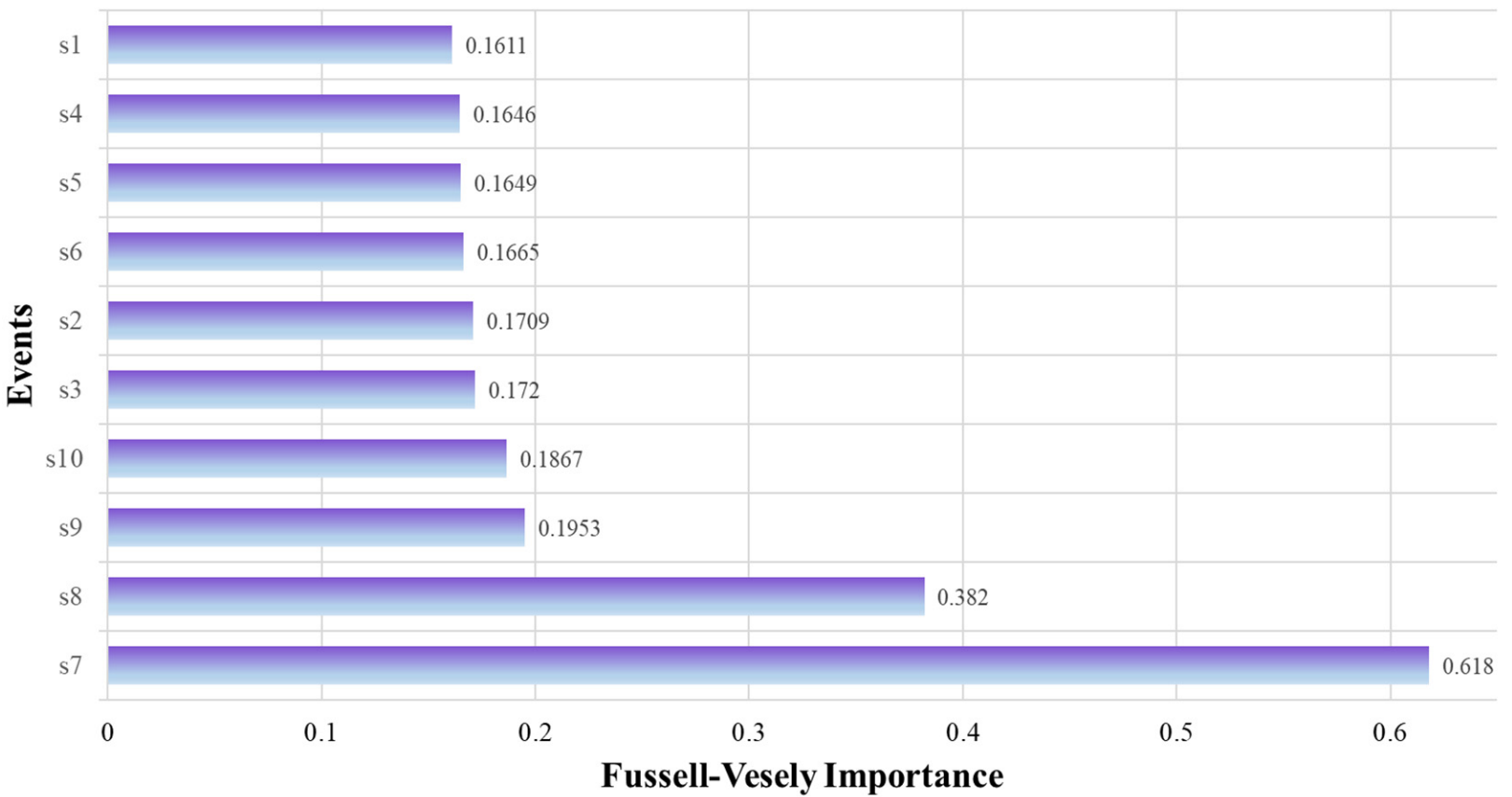

Figure 17. Fussell-Vesely Importance of each basic event of submarine cable accident.

Insufficient buried depth of cables(s7) $>$ No timely maintenance(s8) $>$ Wave wash(s9) $>$ No protection for submarine cables(s10) > No warning sign in the submarine cable laying area(s3) > No filed information about the submarine cable(s2) > Cable near the waterways(s6) > Fishing in submarine cable laying area(s5) > Ship equipment failure(s4) > Bad weather(s1).

\section{Discussion}

According to the previous Fault Tree Analysis, during the operation period, the risks of offshore wind power are infrastructure, equipment and personnel, and navigation. The results show that:

(1) Collapse and corrosion are the main focuses of infrastructure risks of the offshore wind farm operation.

(a) The top three risks for infrastructure collapse are gale, earthquake, and tide.

(b) The top three risks for infrastructure corrosion are untimely overhauling, improper anti-corrosion measures, and salt spray.

(2) Fire, lightning, blade failure, and personnel injury are the main events of equipment and personnel safety accidents.

(a) The main causes of equipment fire are improper fire stopping methods, oil leakage, oily cotton, and other materials.

(b) The main risks of lightning strikes are the high average number of thunderstorm days, poor contact between the flange of the tower and the electrode, and salt spray.

(c) The main causes of turbine blade failure are the loose internal structure of the fan, brake failure, and imbalance impeller.

(d) The main causes of personnel injury are working at height, misoperation, and live inspection.

(3) Ship collisions and submarine cable accidents are the main navigation risks of offshore wind farms.

(a) The risks of ship collisions are collision avoidance failure, bad weather, and customary routes in the wind farm. 
(b) The risks of submarine cable accidents are insufficient buried depth of cables, no timely maintenance, and wave wash.

The following measures are proposed to improve the safety of the operation of offshore wind farms.

(1) Measures for infrastructure safety:

(a) To reduce the risk of collapse, firstly, the design of the wind turbines should be well considered. Secondly, the manufacturing processes need to be improved. Thirdly, the qualified connection between the components should be guaranteed. Besides, periodic inspection and maintenance are indispensable.

(b) To reduce the risk of corrosion, proper anti-corrosion measures for different parts of the turbines in different environments are needed. Moreover, corrosion monitoring and periodic maintenance should be well carried out.

(2) Measures for equipment safety:

(a) For fire prevention, fully functioning, maintenance, and inspection of the Fire Protection Systems are the keys. Refinements of related management regulations are also needed.

(b) For lighting strikes, qualified and complete lighting protection devices are essential.

(c) For blade failure, using proper blade design according to the wind farm location and environment is important. Keeping the smoothness of the surface of the blames is necessary to avoid flutter. Regular wind turbine inspections should be carefully conducted.

(3) Measures for personal safety:

(a) Improvement of the safety management systems and training to strengthen personnel safety awareness are needed.

(b) Professional operation and maintenance ships should be equipped, and early warning systems and First Aid Center are also needed.

(4) Measures for navigation safety:

(a) Optimizing the planning and design before constructing the offshore wind farms is an efficient way to avoid significant impacts on existing navigation routes. Besides, competent traffic management is needed for efficient and safe navigation in and near wind farms.

(b) The precautionary zones should be set where submarine cables lay. The placement of the submarine cables should be fielded in time. Besides, timely repairments are needed once any small faults occur.

\section{Conclusions}

In this paper, the risk characteristics of offshore wind farm operations are analyzed based on the identification of hazards and risk assessment theory. A systematic fault tree analysis of the offshore wind farm operation is carried out. Based on the experience of offshore wind power operation and accident data statistics, and combined with the fault tree analysis method, this paper proposed a top-down system risk modeling method for offshore wind farm operation safety from the perspectives of infrastructure, offshore wind power equipment, and personnel safety, and navigation waters. Based on the risk index of each basic event that is calculated according to experts' judgment, quantitative and qualitative analysis, including the minimum cut set, structural importance degree, and probability importance degree of each risk, are carried out. Consequently, the key factors and importance of offshore wind farm operations are analyzed.

According to the analysis, the main risks to offshore wind farms are collapse, corrosion, fire, lightning strikes, blade failure, personal injury, ship collision, and submarine cable damage accidents. The main causes are gale, untimely overhauling, improper fire stopping methods, and high average number of thunderstorm days, the loose internal structure of 
fan, working at height, collision avoidance failure, and insufficient buried depth of cables. Moreover, suggestions to reduce the operation risk of offshore wind farms are proposed.

The results presented in this manuscript are based on 50 questionnaires, and the risk index for each basic event is the mean value of the answers. For future research, weighting factors to include the impact of the job position and work seniority can be taken into account. Moreover, various data resources can be combined to identify the risk, such as operation data, and AIS data of nearby ships are needed. Besides, validation is important for risk assessment research which should be considered in the next step. Furthermore, other data mining techniques and risk measures can be applied for comparison.

Author Contributions: Conceptualization, X.J. and J.M.; methodology, X.J. and L.C.; formal analysis, X.J. and P.C.; investigation, X.J. and L.C.; writing-original draft preparation, X.J.; writing-review and editing, L.C., J.M. and P.C.; supervision, L.C., J.M. and P.C.; project administration, J.M.; funding acquisition, J.M. and L.C. All authors have read and agreed to the published version of the manuscript.

Funding: This research was funded by the Fundamental Research Funds for the Central Universities (WUT: 2021IVA051).

Institutional Review Board Statement: Not applicable.

Informed Consent Statement: Not applicable.

Data Availability Statement: Data available on request due to restrictions of privacy.

Conflicts of Interest: The authors declare no conflict of interest.

\section{Appendix A}

Table A1. An overview of accidents and risk factors in related research.

\begin{tabular}{|c|c|c|}
\hline Event & Risk Factors & Ref. \\
\hline \multirow{3}{*}{$\begin{array}{l}\text { Infrastructure } \\
\text { risks }\end{array}$} & The failure of a primary steel member & \multirow{3}{*}{ [5] } \\
\hline & $\begin{array}{l}\text { Exposed to harsh and complex stresses (corrosion, physical loads, biological attack, and } \\
\text { mechanical damage) }\end{array}$ & \\
\hline & $\begin{array}{l}\text { Environment (violent winds, large waves, temperature changes, infrared radiation, and ice and } \\
\text { snow loads) }\end{array}$ & \\
\hline \multirow{7}{*}{ Collapse } & Fractured bolts & \multirow{5}{*}{ [6] } \\
\hline & Human factors (including both "ethical" failures and accidents) & \\
\hline & Design flaws (many of which are often the result of unethical practices) & \\
\hline & Material failures & \\
\hline & Extreme conditions or environments & \\
\hline & Collisions between vessels and offshore wind turbines & [19] \\
\hline & Scouring & [20] \\
\hline \multirow{7}{*}{ Corrosion } & Unsuitable constructive design & \multirow{4}{*}{ [3] } \\
\hline & Coating failure (coating deterioration) and corrosion (metal loss) & \\
\hline & Mechanical loading & \\
\hline & Stability and function of the steel structures of offshore wind constructions & \\
\hline & $\begin{array}{l}\text { The mechanical variables include: loading frequency, stress intensity factor, loading waveform, load } \\
\text { interaction effects (variable amplitude loading), residual/mean stresses, material type and geometry }\end{array}$ & \multirow{3}{*}[4]{} \\
\hline & $\begin{array}{l}\text { The metallurgical variables are microstructure and material composition, mechanical properties, heat } \\
\text { treatment, etc. }\end{array}$ & \\
\hline & $\begin{array}{l}\text { The environmental variables include: temperature, } \mathrm{pH} \text {, level of cathodic protection, coating type, oxygen } \\
\text { concentration, etc. }\end{array}$ & \\
\hline
\end{tabular}


Table A1. Cont.

Event

Risk Factors

Ref.

Oxygen and humidity

Site-specific factors (water temperature, salinity, chlorinity, water depth, and current speed)

The structures have long-term exposure to humidity with high salinity

Intensive influence of UV light

Wave action

Bird droppings

Mechanical load (e.g., ice drifts or floating objects)

Irregular inspection intervals

Maintenance and repair costs

Design life

Chemical attack

Abrasive action of waves and other substances in suspension (ice drift or floating objects)

The attack of microorganisms

Equipment and ignition source concentration

All offshore wind turbines are unattended

Wind turbine electrical equipment failure

Overload

Short circuit

Fire Grounding fault

Technical defects

Improper selection of electrical and electronic components

Bolt loosening leads to high contact resistance

Excessive exposure to humidity, salt fog, and other environmental conditions

Limited operating experience

Thunderstorm activity

The topographical conditions

Lightning

The height of the wind turbines

The number of tall structures around

Lightning

Lightning strikes

Strong winds

Large waves

Maintenance crew and spare parts cannot reach the wind farm immediately

Blade failure

Lightning

Fatigue cracks

Environmental condition such as the free corrosion conditions

Loading conditions

Microstructure

Welding procedure

Residual stresses 
Table A1. Cont.

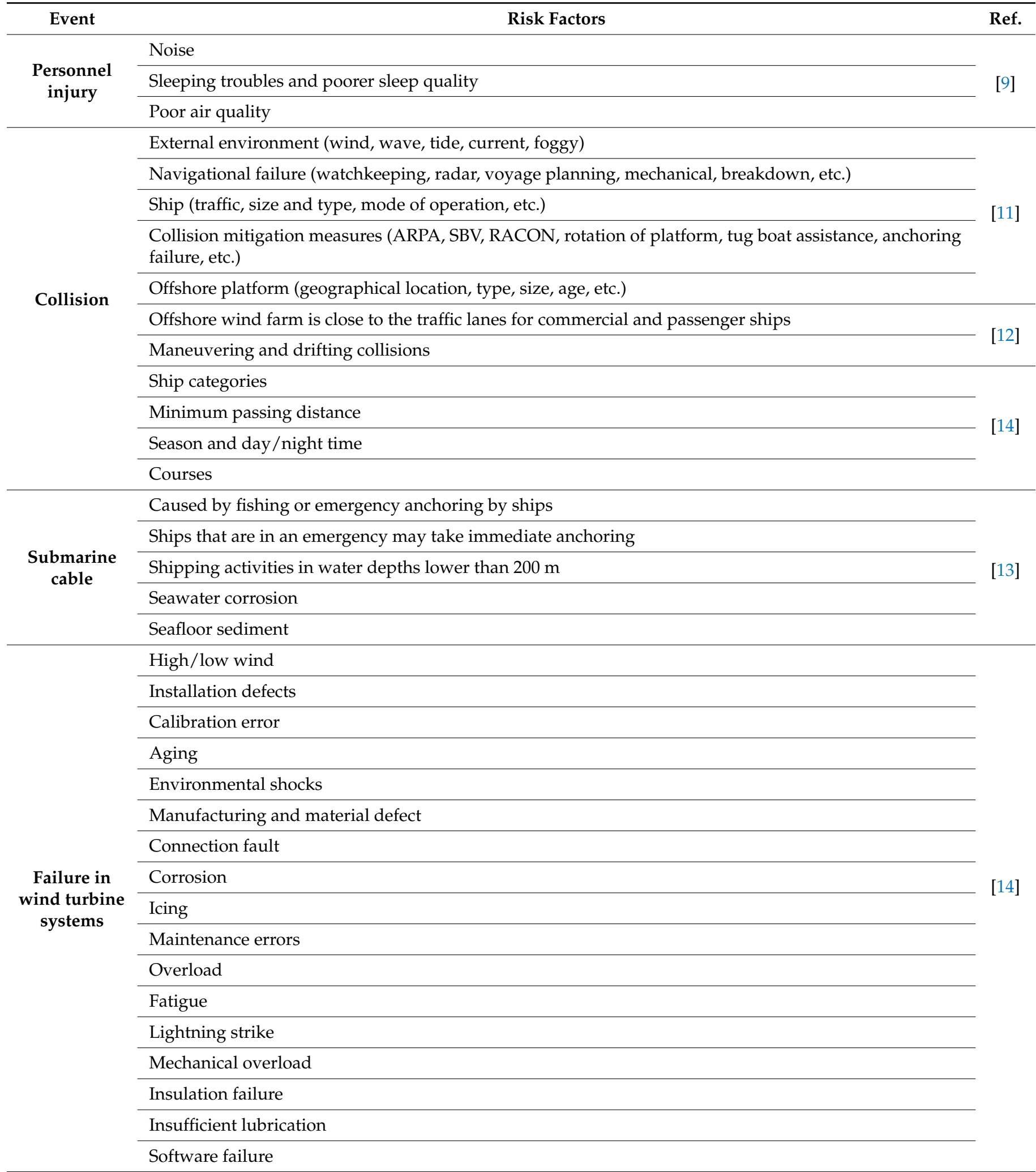




\section{Appendix B}

The questionnaire of identification of risk factors of operation of offshore wind farms are as follows. Fields marked with an asterisk $(*)$ are required fields and must be filled.

\section{Risk factors of offshore wind farms}

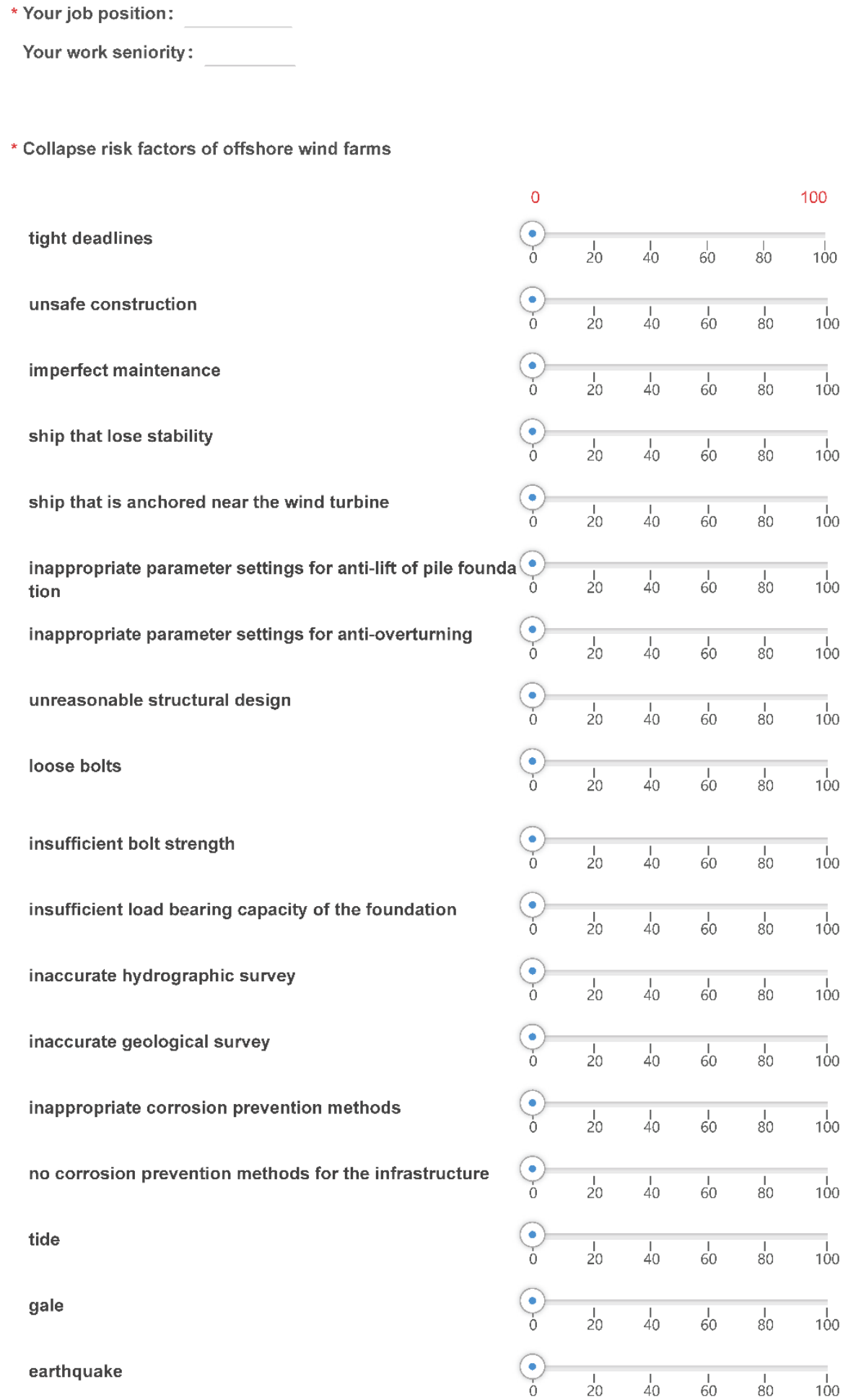


* Corrosion risk factors of offshore wind farms

untimely overhauling

improper anti-corrosion measures

improper equipment selection

salt spray

tide

marine organisms attached to the equipment structure

scouring

metal structure of steel

* Fire risk factors of offshore wind farms

improper fire stopping methods

lightning strike

improper electrical operation

mechanical damage to electrical devices

salt spray corrosion

overload

vulnerabilities in device's manufacturing

violation of safety regulations

improper selection and installation of electrical devices

irrational design of electrical circuit

welding

small space

overspeed
100
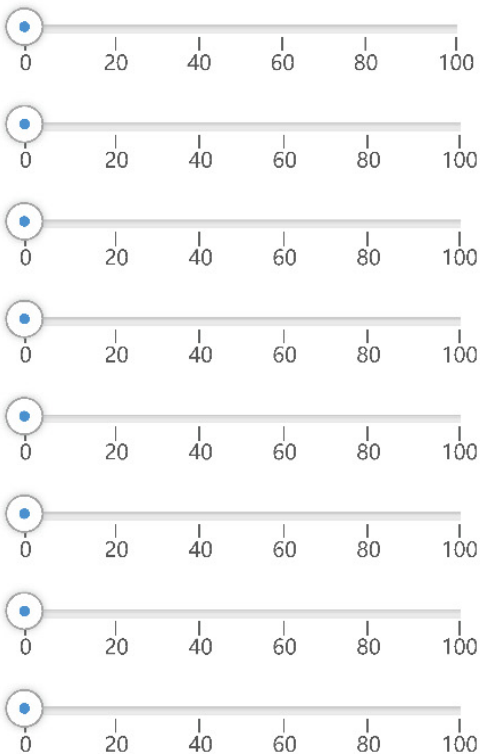

0

100
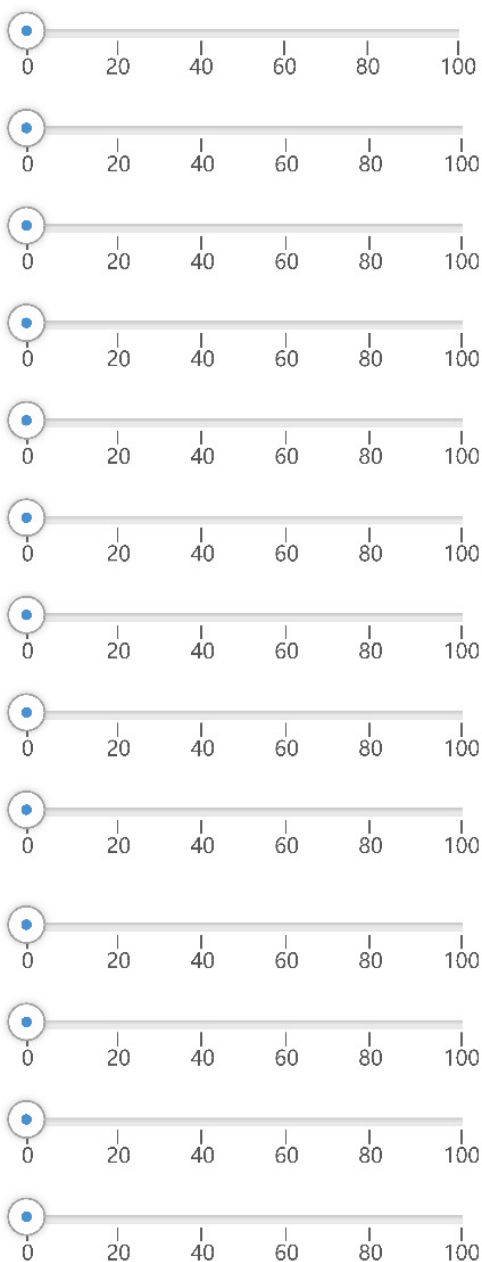
mechanical friction

Increases in Electrical Contact Resistance

poor ventilation

oil leakage

oily cotton and other materials
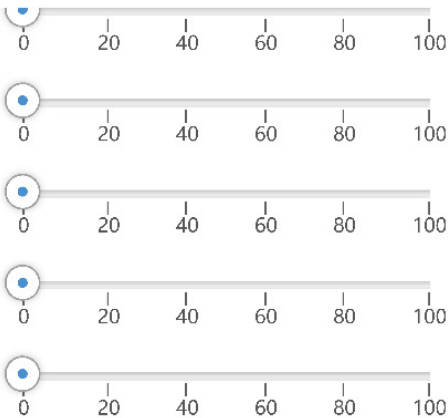

* Lightning stike risk factors of offshore wind farms

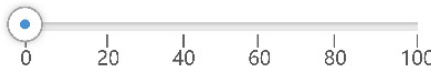

high average number of thunderstorm days

poor contact between the flange of the tower and the electr ode

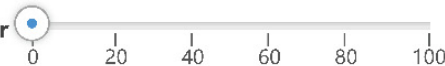

large device sizes

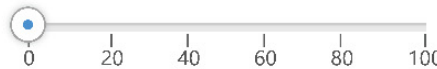

salt spray

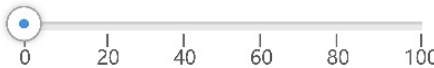

widespread use and exposure of composite materials

no regular inspection of lightning protection facilities

unreliable conductive pathway
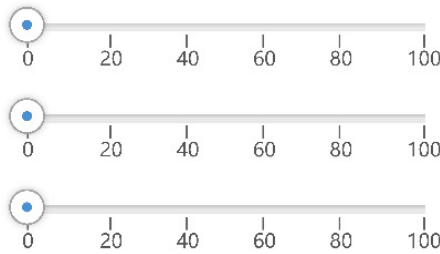

unqualified grounding resistance

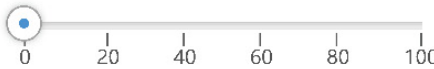

limited thermal capacity of the grounding devices

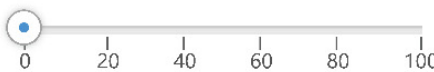

problems in grounding grid construction

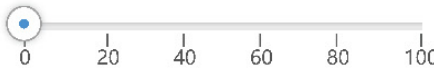

local corrosion of grounding devices

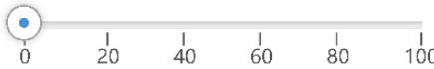

poor design of lightning rod

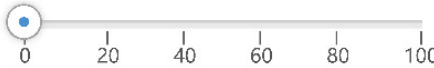

wrong location of the lightning rod

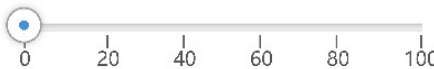

errors in the design of equalizing network

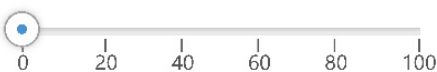

* Blade failure risk factors of offshore wind farms

hyperthermic environment

effect of chemical medium
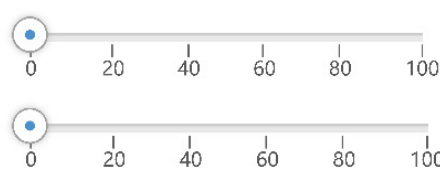

ultraviolet irradiation

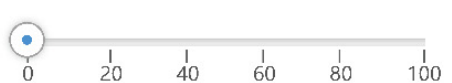


erosion by atmospheric particles

defects in blade design

immature manufacturing processes

imbalance impeller

loose internal structure of fan

gale

no timely repair

lightning

unqualified grounding resistance

high humidity blade surface

decrease in blade insulation corrosion by salt spray

inexperienced manufacturers
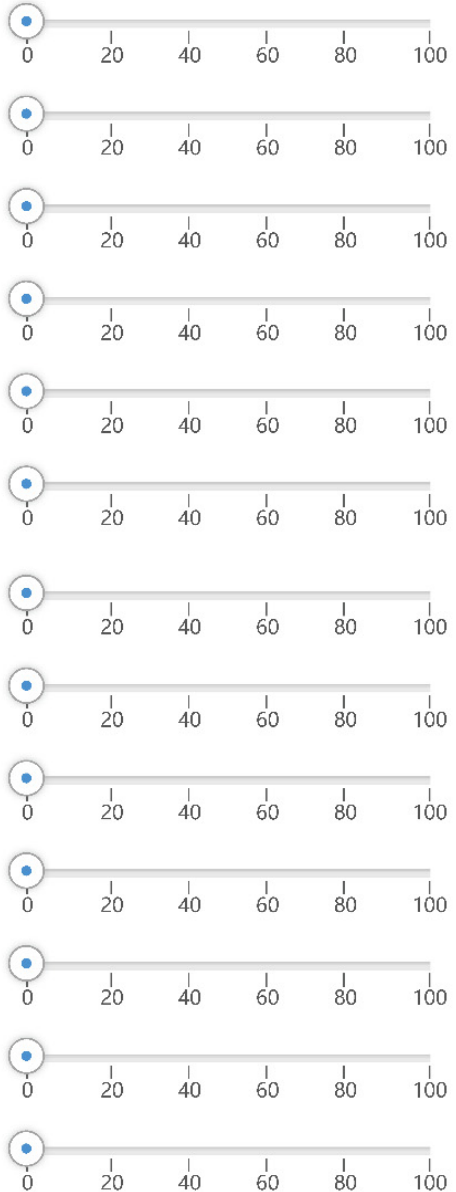

cracks in the connection between lightning attractor and b/
ade erosion by particles

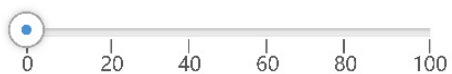

erosion by water vapor

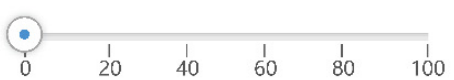

invasion of impurities such as particulate matter

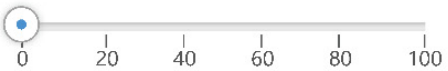

fatigue

long service time of fan
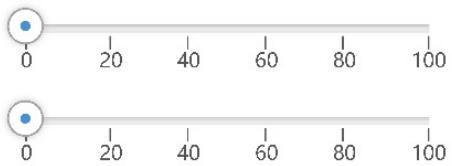

over-power operation

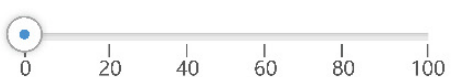

brake failure

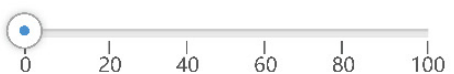

oil spilling

crack

fouling on the surface of blades
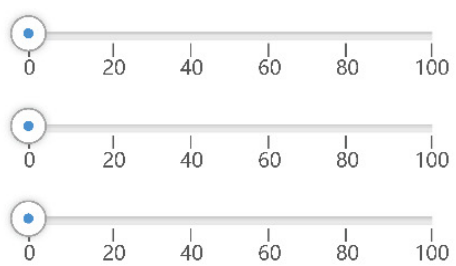

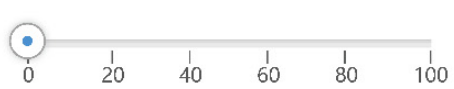


noise

working at height

landing and leaving the fan

residual charge inline

wrong operation of power switch

lightning strike

live inspection

misoperation

poor mechanical parts assembly

mechanical equipment

improper personnel protection equipment

violation of the operation procedure

fracture of protection safety rod

wrong fixed position of safety ropes

improper use of protection devices

no professional operation and maintenance ships

maneuvering error

* Collision risk factors of offshore wind farms

collision avoidance failure

lack of lookout

low visibility

operation error

electromagnetic interference from wind farms

failure of navigation equipment
100

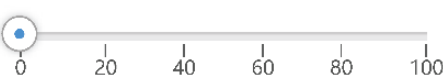

$\begin{array}{cccccc}- & 1 & 1 & 1 & 1 & 1 \\ 0 & 20 & 40 & 60 & 80 & 100\end{array}$

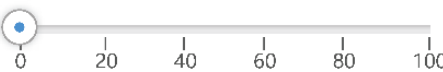

$\begin{array}{rrrrrr}1 & 1 & 1 & 1 & 1\end{array}$

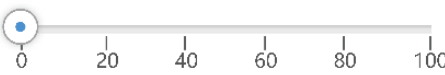

$\begin{array}{cccccc}- & 1 & 1 & 1 & 1 & 1 \\ 0 & 20 & 40 & 60 & 80 & 100\end{array}$

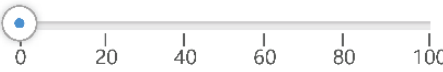

$\begin{array}{llllll}1 & 1 & 1 & 1 & 1\end{array}$
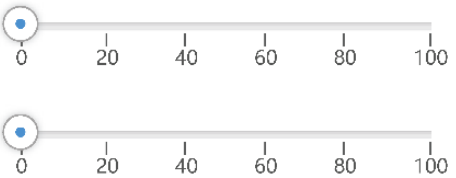

$\begin{array}{llllll}0 & 1 & 1 & 1 & 1 & 1 \\ 0 & 20 & 40 & 60 & 80 & 100\end{array}$

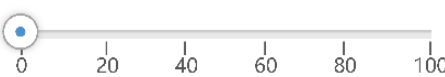

$\begin{array}{cccccc}- & 1 & 1 & 1 & 1 & 1 \\ 0 & 20 & 40 & 60 & 80 & 100\end{array}$

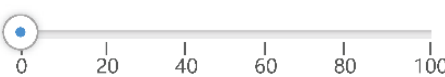

$\begin{array}{cccccc}1 & 1 & 1 & 1 & 1 \\ 0 & 20 & 40 & 60 & 80 & 100\end{array}$

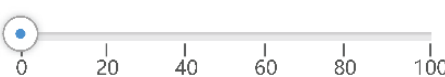

$\begin{array}{llllll}- & 1 & 1 & 1 & 1 & 1 \\ 0 & 20 & 40 & 60 & 80 & 100\end{array}$

0

100
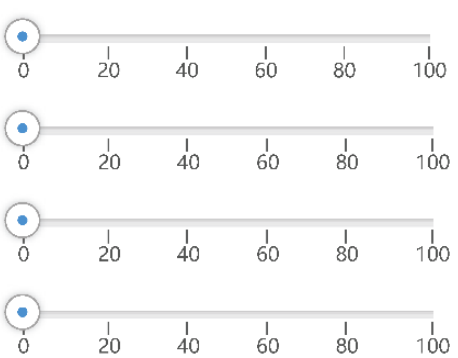

$\begin{array}{cccccc}- & 1 & 1 & 1 & 1 & 1 \\ 0 & 20 & 40 & 60 & 80 & 100\end{array}$

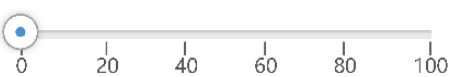


bad weather

mooring system failure

steering failure

propeller failure

improper anti-collision facilities of fan foundation
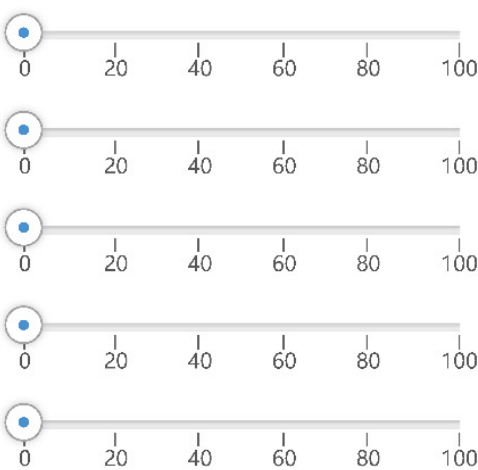

no effective reminder in the late period of collision avoida nce process

failure in remote monitoring

customary routes in the wind farm

equipment near the waterways
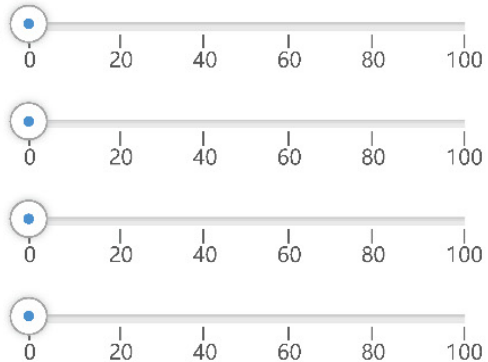

* Submarine cable risk factors of offshore wind farms

0

100

bad weather

no filed information about the submarine cable
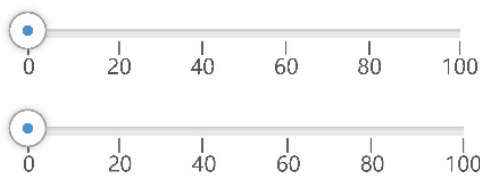

no warning sign in the submarine cable laying area

ship equipment failure
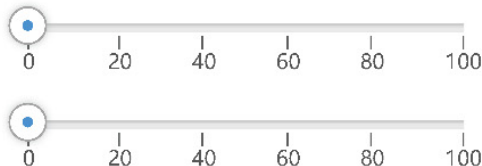

fishing in submarine cable laying area

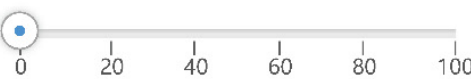

cable near the waterways

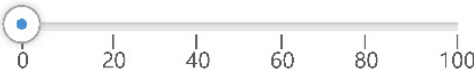

insufficient buried depth of cables

no timely maintenance
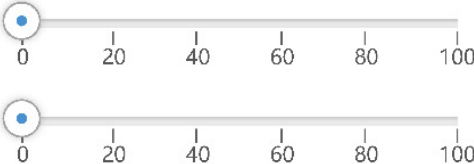

wave wash

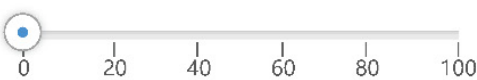

no protection for submarine cables

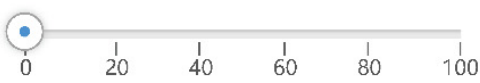

\section{References}

1. Reimers, B.; Özdirik, B.; Kaltschmitt, M. Greenhouse gas emissions from electricity generated by offshore wind farms. Renew. Energy 2014, 72, 428-438. [CrossRef]

2. G+ Global Offshore Wind Health and Safety Organisation. Available online: https://www.gplusoffshorewind.com/ (accessed on 25 June 2020). 
3. Momber, A. Quantitative performance assessment of corrosion protection systems for offshore wind power transmission platforms. Renew. Energy 2016, 94, 314-327. [CrossRef]

4. Adedipe, O.; Brennan, F.; Kolios, A. Review of corrosion fatigue in offshore structures: Present status and challenges in the offshore wind sector. Renew. Sustain. Energy Rev. 2016, 61, 141-154. [CrossRef]

5. Price, S.J.; Figueira, R.B. Corrosion Protection Systems and Fatigue Corrosion in Offshore Wind Structures: Current Status and Future Perspectives. Coatings 2017, 7, 25. [CrossRef]

6. Chou, J.-S.; Tu, W.-T. Failure analysis and risk management of a collapsed large wind turbine tower. Eng. Fail. Anal. 2011, 18, 295-313. [CrossRef]

7. Xing, H.; Liu, Q.-A.; Zheng, Q.-G.; Wang, Y.-X. Study on risk analysis and protection of electrical fire for offshore wind turbines Renew. Energy Resour. 2013, 109-113.

8. Becerra, M.; Long, M.; Schulz, W.; Thottappillil, R. On the estimation of the lightning incidence to offshore wind farms. Electr. Power Syst. Res. 2018, 157, 211-226. [CrossRef]

9. Garrido, M.V.; Mette, J.; Mache, S.; Harth, V.; Preisser, A.M. Sleep quality of offshore wind farm workers in the German exclusive economic zone: A cross-sectional study. BMJ Open 2018, 8, e024006. [CrossRef]

10. Chao, H.; Hu, B.; Xie, K.; Tai, H.-M.; Yan, J.; Li, Y. A Sequential MCMC Model for Reliability Evaluation of Offshore Wind Farms Considering Severe Weather Conditions. IEEE Access 2019, 7, 132552-132562. [CrossRef]

11. Mujeeb-Ahmed, M.; Seo, J.K.; Paik, J.K. Probabilistic approach for collision risk analysis of powered vessel with offshore platforms. Ocean Eng. 2018, 151, 206-221. [CrossRef]

12. Bela, A.; Le Sourne, H.; Buldgen, L.; Rigo, P. Ship collision analysis on offshore wind turbine monopile foundations. Mar. Struct. 2017, 51, 220-241. [CrossRef]

13. Jiang, D.; Wu, B.; Yang, X.; van Gelder, P. A fuzzy evidential reasoning based approach for submarine power cable routing selection for offshore wind farms. Ocean Eng. 2019, 193, 106616. [CrossRef]

14. Shafiee, M.; Dinmohammadi, F. An FMEA-Based Risk Assessment Approach for Wind Turbine Systems: A Comparative Study of Onshore and Offshore. Energies 2014, 7, 619-642. [CrossRef]

15. Marugán, A.P.; Márquez, F.P.G.; Pérez, J.M.P. Optimal Maintenance Management of Offshore Wind Farms. Energies 2016, 9, 46. [CrossRef]

16. Chen, W.-M.; Kim, H.; Yamaguchi, H. Renewable energy in eastern Asia: Renewable energy policy review and comparative SWOT analysis for promoting renewable energy in Japan, South Korea, and Taiwan. Energy Policy 2014, 74, 319-329. [CrossRef]

17. Sinha, Y.; Steel, J.A. Failure Prognostic Schemes and Database Design of a Software Tool for Efficient Management of Wind Turbine Maintenance. Wind. Eng. 2015, 39, 453-477. [CrossRef]

18. Wu, W.-S.; Yang, C.-F.; Chang, J.-C.; Château, P.-A.; Chang, Y.-C. Risk assessment by integrating interpretive structural modeling and Bayesian network, case of offshore pipeline project. Reliab. Eng. Syst. Saf. 2015, 142, 515-524. [CrossRef]

19. Yu, Q.; Liu, K.; Chang, C.-H.; Yang, Z. Realising advanced risk assessment of vessel traffic flows near offshore wind farms. Reliab. Eng. Syst. Saf. 2020, 203, 107086. [CrossRef]

20. Fazeres-Ferradosa, T.; Taveira-Pinto, F.; Romão, X.; Vanem, E.; Reis, M.; Das Neves, L. Probabilistic design and reliability analysis of scour protections for offshore windfarms. Eng. Fail. Anal. 2018, 91, 291-305. [CrossRef]

21. Lee, Y.-S.; Choi, B.-L.; Lee, J.H.; Kim, S.Y.; Han, S. Reliability-based design optimization of monopile transition piece for offshore wind turbine system. Renew. Energy 2014, 71, 729-741. [CrossRef]

22. Yang, H.; Zhu, Y.; Lu, Q.; Zhang, J. Dynamic reliability based design optimization of the tripod sub-structure of offshore wind turbines. Renew. Energy 2015, 78, 16-25. [CrossRef]

23. Elsayed, A.E. Reliability Engineering, 2nd ed.; John Wiley \& Sons, Inc.: Hoboken, NJ, USA, 2012. 